\title{
Dementia-Related Education and Support Service Availability, Accessibility, and Use in Rural Areas: Barriers and Solutions*
}

\author{
Melanie Bayly, Debra Morgan, Amanda Froehlich Chow, Julie Kosteniuk, and Valerie Elliot \\ Canadian Centre for Health and Safety in Agriculture, University of Saskatchewan
}

\begin{abstract}
RÉSUMÉ
Le présent examen de la portée visait à recenser et à synthétiser les publications relatives aux services d'éducation et de soutien destinés aux personnes atteintes de démence et à leurs aidants vivant en milieu rural à travers le monde. Les objectifs spécifiques comprenaient l'examen des besoins en matière d'éducation et de services de soutien, la disponibilité et l'utilisation de ces services, les obstacles limitant l'accès et leur utilisation, et les solutions à ces obstacles. Des articles empiriques en anglais (2381) publiés au cours des 20 dernières années ont été identifiés dans MEDLINE, CINAHL, PSYCINFO et EMBASE à l'aide de mots-clés liés à la démence, à la ruralité, aux services de soutien et à l'éducation. Les articles ont été analysés selon la méthodologie de l'examen de la portée en cinq étapes présentée par Arksey et O’Malley (2005) et selon les recommandations de Levac et ses collaborateurs (2010). Les données de 68 articles ont été consignées dans un fichier Excel après une analyse des textes. Les résultats indiquent que la disponibilité des services de soutien et d'éducation liés à la démence en milieu rural est restreinte, en particulier pour les services de répit et les programmes de jour. L'utilisation des services variait d'une étude à l'autre, et était notamment limitée par le manque de connaissances sur les services, par des questions pratiques et liées aux ressources (p. ex. transport, finances), par les valeurs et les croyances, ainsi que par la stigmatisation et les perceptions négatives associées aux services. Les solutions comprenaient des services personnalisés et axés sur la personne, l'offre de services technologiques, l'aide à l'accessibilité, la collaboration interorganisationnelle, la formation sur les services et l'instauration d'un «point d'accès » pour leur utilisation. Les résultats illustrent à la fois les défis et les innovations prometteuses en matière d'éducation et de services de soutien liés à la démence en milieu rural.
\end{abstract}

\begin{abstract}
This scoping review mapped and synthesized published literature related to education and support services for individuals with dementia and their caregivers living rurally. Specifically, we investigated education and support service needs, availability and use of services, barriers to service access and use, and solutions to these barriers. Empirical, Englishlanguage articles $(2,381)$ were identified within MEDLINE, CINAHL, PSYCINFO, and EMBASE. Articles were screened according to Arksey and O'Malley's (2005) five-stage scoping review methodology and the recommendations of Levac et al. (2010). Findings suggest limited availability of rural dementia-related support and education services, particularly respite care and day programs. Service use varied across studies, with barriers including low knowledge regarding services, practicality, and resource issues (e.g., transportation, financial), values and beliefs, stigma, and negative perceptions of services. Solutions included tailored and person-centred services, technological service provision, accessibility assistance, inter-organization collaboration, education regarding services, and having a "point of entry" to service use.
\end{abstract}

* Funding for this research was provided by the Saskatchewan Health Research Foundation through a partnership with the Canadian Institutes of Health Research, in support of the Canadian Consortium on Neurodegeneration in Aging (CCNA) (grant number 3431).

Manuscript received: / manuscrit reçu : 13/08/2018

Manuscript accepted: / manuscrit accepté : 01/06/2019

Mots-clés : vieillissement, démence, services de soutien, éducation, rural, examen de la portée

Keywords: aging, dementia, support services, education, rural, scoping review

Canadian Journal on Aging / La Revue canadienne du vieillissement 39 (4) : 545-585 (2020)

Copyright (C) Canadian Association on Gerontology 2020. This is an Open Access article, distributed under the terms of the Creative Commons Attribution licence (http://creativecommons.org/licenses/by/4.0/), which permits unrestricted re-use, distribution, and reproduction in any medium, provided the original work is properly cited. 
La correspondance et les demandes de tirés-à-part doivent être adressées à : / Correspondence and requests for offprints should be sent to:

Melanie Bayly, Ph.D.

Canadian Centre for Health and Safety in Agriculture

104 Clinic Place

P. O. Box 23

University of Saskatchewan

Saskatoon, SK S7N 2Z4

(melanie.bayly@usask.ca; mke177@mail.usask.ca)

Dementia has a huge impact globally: 46.8 million people were living with dementia in 2015, and this number is projected to almost double every 20 years (Prince et al., 2015). As national populations age and rates of dementia increase, it will become increasingly important to provide supports for people to live well with dementia. This means providing dementia care that is person-centred, seamless, and coordinated, and to provide support such that the needs of people with dementia and their caregivers are anticipated and met as they arise (Prince, Comas-Herrera, Knapp, Guerchet, $\&$ Karagiannidou, 2016). The majority of people with dementia worldwide live in the community, most with the support of informal caregivers and/or community services (Gould \& Basta, 2013; Kasper, Freedman, Spillman, \& Wolff, 2015; Lepore, Ferrell, \& Wiener, 2017). A recent Canadian estimate suggested that, in 2016, 61 per cent of older adults (more than 261,000 individuals) with dementia were living in their own homes (Canadian Institute for Health Information, 2018), while data from the United States suggests approximately 81 per cent of individuals with dementia are community-dwelling (Lepore et al., 2017). Community residence is particularly prevalent in low- and middle-income countries, with 94 per cent of people with dementia residing at home (and family providing most of the care) compared to 78 per cent in higher income countries (Alzheimer's Disease International, 2009; Wimo, Jönsson, Bond, Prince, \& Winblad, 2013).

Individuals with dementia and their caregivers express a number of education and support needs that vary throughout the different stages of dementia, and services exist (particularly in higher-resource locations) that are intended to meet these needs. These include information resources, caregiver training/skillbuilding, support groups, counseling, respite care, care coordination programs, transportation services, delivery of groceries and meals, personal care, and care planning (Whitlatch \& Orsulic-Jeras, 2018). Such services can help support caregivers, as well as help people with dementia age in place. Although caregiver support and living well with dementia in the community are distinct concepts, many of these services benefit both caregivers and persons with dementia.
A growing body of literature suggests that education and support services for people with dementia and caregivers have positive effects, although these effects may be limited to specific outcomes, and some programs require further evidence of efficacy (Dam, de Vugt, Klinkenberg, Verhey, \& van Boxtel, 2016; Dawson, Bowes, Kelly, Velzke, \& Ward, 2015; Dickinson et al., 2017; Huis in het Veld, Verkaik, Mistiaen, van Meijel, \& Francke, 2015; Jensen, Agbata, Canavan, \& McCarthy, 2015; Vandepitte et al., 2016). For example, Dickinson et al. (2017) concluded in their metasystematic review that well designed, multi-component psychosocial caregiver interventions increase psychological well-being in caregivers and delay institutionalization of people with dementia. Such interventions are an example of how support aimed specifically at caregiver well-being has also been found to help persons with dementia age in place longer. In a systematic review on respite care, day care (but not temporary admission respite) was found to decrease caregiver burden and stress as well as diminish reactive behaviours in people with dementia (Vandepitte et al., 2016). A recent metaanalysis has suggested that although educational interventions for caregivers are not a panacea for supporting those with dementia to age in place, they have a moderate effect on caregiver burden and may decrease caregiver depression (Jensen et al., 2015).

While many support and education services for people with dementia and their caregivers have the potential to increase well-being and support living well with dementia, such services may not be readily available in lower-resource countries, and barriers to accessibility and use may exist even in high-income countries (World Health Organization, 2015). Rurality impacts the availability and accessibility of services, with geographic isolation, small and dispersed populations, and limited access to health professionals serving as barriers to rural health service delivery (Bourke, Humphreys, Wakerman, \& Taylor, 2012; Innes, Cox, Smith, \& Mason, 2006). Shortages of human health resources (including specialist services) and limited local health and support resources have been repeatedly reported in rural Canadian contexts (e.g., Canadian Home Care Association, 2006; Dal Bello-Haas, Cammer, Morgan, 
Stewart, \& Kosteniuk, 2014a; Morgan, Semchuk, Stewart, \& D'Arcy, 2002; Morgan et al., 2015). For example, Morgan et al. (2015) found that while most basic health care services were considered accessible to rural Saskatchewan residents affected by dementia, there was a paucity of services specifically for individuals with dementia and their caregivers (e.g., dementia screening, multidisciplinary team assessment, counseling and caregiver support groups, and dementia-specific long-term care services).

These issues are not unique to the Canadian context: Szymczynska, Innes, Mason, and Stark (2011) identified limited access to diagnostic and post-diagnostic services for dementia as a significant issue for rural communities within Scotland, Canada, Tasmania, and Australia. Rural health care providers working with Canadian families affected by dementia have also reported professional isolation and the need for continuing education opportunities, which may affect their ability to provide best-quality care (Dal Bello-Haas et al., 2014a; Forbes et al., 2012; Morgan, Innes, \& Kosteniuk, 2011). These resource issues, along with transportation difficulties, may contribute to rural/ urban inequities in dementia health care and support that have been identified in higher-income countries (Prince et al., 2016).

Given the potential utility of support and education services for people with dementia and their caregivers to live well in their communities, it is important to identify the scope of services available to and needed by rural populations globally, and the existing barriers to their accessibility and use. Moreover, it is important to examine potential solutions to these barriers, in order to design dementia-related services that successfully meet support and education needs. The purpose of the current scoping review was therefore to investigate the support and education needs of people with dementia and their caregivers living in rural areas; availability and use of support and education services; barriers to access and use of services; and solutions to overcome these barriers. A scoping review allowed us to systematically map the research pertaining to these questions, to synthesize barriers and solutions that could be helpful for intervention development, and to identify gaps in knowledge.

\section{Methods}

This work was guided by Arksey and O'Malley's (2005) five-step framework for scoping reviews, with additional reference to Levac, Colquhoun, and O'Brien's (2010) recommendations. Additionally, the recently published guidelines for reporting scoping reviews (Tricco et al., 2018) informed the final iteration of this article. The methodological stages outlined by Arksey and $\mathrm{O}^{\prime}$ Malley involve (a) identifying the research question, (b) identifying relevant studies, (c) selecting the studies, (d) charting the data, and (e) collating, summarizing, and reporting the results. A protocol documenting the research questions and methods of this scoping review was created prior to commencing the review; this protocol was not documented for publication but can be requested from the corresponding author.

In line with Levac et al. (2010), we adopted a team-based approach that involved the collaborative development of research questions, search strategies, and charting categories for this and other concurrent reviews. Our team consisted of all five authors, who met bi-weekly to discuss progress, challenges, and findings. Team members also acted as secondary independent reviewers during the screening process.

\section{Identifying the Research Question}

As suggested by Levac et al. (2010), we carefully considered the review population, concepts, and outcomes of interest. People with dementia living in rural communities and their caregivers were the populations of interest, since support and education services are important for the well-being of both of these groups. To comprehensively explore dementia-related support and education services for residents of rural areas, six concepts were vital to consider: needs, availability, use, accessibility, barriers, and solutions. The following research questions were therefore developed: (a) What types of support service and education needs are being expressed by people with dementia and their caregivers in rural areas?; (b) What types of services are available and used?; (c) What are the reported barriers to service accessibility and use in these populations? and (d) What are the potential solutions to these barriers, identified by participants and reflected in support and education interventions?

Clarification of "support and education services" was achieved through a review of recent reports related to dementia care and support within the community (Health Quality Ontario, 2018; National Institute for Health and Care Excellence, 2010, 2013; United Kingdom Department of Health, 2013; World Health Organization, 2012;). Education services were defined as those providing education related to dementia, available services, self-care, resources and supports; or those providing care skills to people with dementia or their caregivers. Support services corresponded closely to those termed "human services" by Toseland et al. (1999) and included daily/personal care, household tasks, social or recreational programs and support, transportation, end-of-life care, psychoeducation, individual support and counselling, support groups, and respite care. 


\section{Identifying Relevant Studies}

Search terms were reviewed by a University Health Sciences librarian, and were related to dementia and Alzheimer's disease, rurality, support (in the iterations described above), and education (see Table 1). After initial testing and refinement of terms, we performed the search on August 16, 2017, using the databases MEDLINE, CINAHL, PSYCINFO, and EMBASE. According to the purpose and scope of the review, we searched for articles from the past 20 years (1997-2017); this offered a relatively current perspective.

\section{Study Selection}

From the 2,381 references we identified, 1,261 remained after de-duplication in Endnote. These articles were uploaded into the review software DistillerSR. Titles and abstracts were reviewed by $\mathrm{MB}$ and a second reviewer $(\mathrm{JK}, \mathrm{VE})$ to determine whether they met the inclusion criteria (Table 2). Following the first round of exclusions, 174 articles remained for full-text independent review by MB and AFC. During both levels of review, all conflicts were resolved with a bias towards inclusion. Following full-text review (completed
November 25), 83 articles remained at the onset of data charting. However, as noted by Levac et al. (2010), the study selection and data charting are iterative processes, and we subsequently removed another 15 during charting mainly because they were descriptions of service models or too peripheral to the foci of this review (Figure 1).

\section{Charting the Data}

The first author extracted relevant data from the 68 remaining articles, which were charted into a Microsoft Excel file that was pilot-tested and refined by the team prior to use. Charting categories included (a) author/s; (b) year; (c) country; (d) purpose of study; (e) type of study (descriptive or intervention); (f) brief description of intervention if applicable; (g) study sample (rurality, population description, sex, age, ethnicity, caregiving relationships, and dementia diagnoses); (h) definition of rural; (i) methodology; (j) service availability, accessibility, and use; (k) service needs; (l) barriers; (m) solutions; (n) outcomes (for intervention studies); (o) key findings/conclusions related to the scoping review questions; and (p) sex and gender-

Table 1: Search terms used with EMBASE database

\begin{tabular}{|c|c|c|c|}
\hline Rural Terms & \multicolumn{2}{|c|}{ Support and Education Terms } & Population Terms \\
\hline $\begin{array}{l}\text { rural* }^{*} \\
\text { rural health care/ } \\
\text { rural area/ } \\
\text { urban rural difference/ } \\
\text { rural population/ }\end{array}$ & $\begin{array}{l}\text { exp social support/ } \\
\text { social support } \\
\text { social } \\
\text { patient education/ } \\
\text { education* } \\
\text { needs } \\
\text { needs assessment/ } \\
\text { information* } \\
\text { information adj2 need? } \\
\text { service? } \\
\text { recreation* } \\
\text { transport* } \\
\text { patient transport/ } \\
\text { exp counseling/ } \\
\text { counsel* } \\
\text { patient care planning/ }\end{array}$ & $\begin{array}{l}\text { self care/ } \\
\text { respite care/ } \\
\text { exp day care/ } \\
\text { hospice care/ } \\
\text { home care/ } \\
\text { elderly care/ } \\
\text { help* } \\
\text { program development/ } \\
\text { program evaluation/ } \\
\text { program } \\
\text { exp telemedicine/ } \\
\text { tele* } \\
\text { phone } \\
\text { access* } \\
\text { health care access/ }\end{array}$ & $\begin{array}{l}\text { exp dementia/ } \\
\text { dement* } \\
\text { Alzheimer* } \\
\text { caregiv* }^{*} \\
\text { carer? } \\
\text { care }\end{array}$ \\
\hline
\end{tabular}

Note. "/" indicates MESH terms. All other terms were searched using .mp.

\section{Table 2: Criteria for inclusion in scoping review}

\section{Inclusion Criteria}

1. Article presents peer-reviewed, empirical research

2. Article is English-language

3. Study focus is on dementia

4. Individuals with dementia are living in the community (not institutional settings)

5. Study participants are rural or providing services to a rural population, OR rural and urban participants are compared/analysed separately, OR more than $2 / 3$ of the participants are rural and rural-specific findings or conclusions are presented

6. Study includes information on dementia support or education services, interventions, needs, or service barriers, for either people with dementia or their informal caregivers 


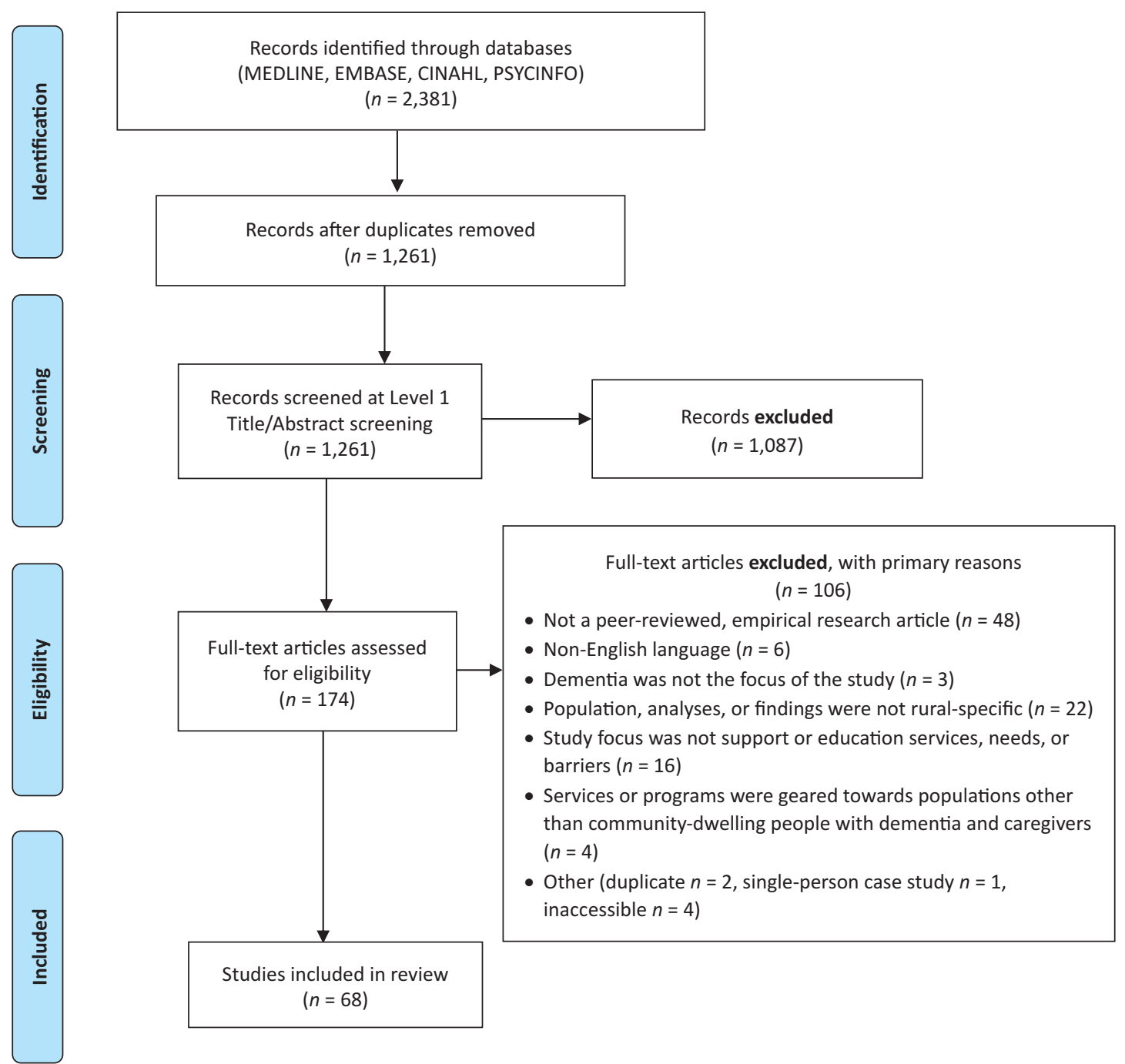

Figure 1: PRISMA flow diagram of the study selection process

related findings. Data within these categories formed the basis of our analyses.

\section{Collating, Summarizing, and Reporting the Results}

As recommended by Levac et al. (2010), we used extracted data to develop a descriptive overview of study characteristics (Table 3). Findings related to the main research concepts were derived through thematic analysis and description. Descriptive and intervention studies are reported separately because they largely answered different research questions. For each descriptive study (those that did not evaluate an intervention/programming), we reported data pertaining to education and support service needs, use, and availability, in addition to use and accessibility barriers that the study participants reported (Table 4). For each intervention study, a brief description and main outcomes are reported, along with ways the intervention incorporated solutions to use and accessibility barriers (Table 5). Finally, Table 6 depicts accessibility and use barriers with literature-based suggestions for how they can be ameliorated.

\section{Findings}

The 68 studies spanned multiple geographical settings, with the largest proportion $(78 \%)$ conducted in North America $(n=38)$ and Europe $(n=15)$. Frequencies (see Table 3) illustrate a non-linear increase in the number of articles over the past 20 years. There was an emphasis on qualitative methodologies among descriptive articles and quantitative work in intervention articles. Of the quantitative intervention studies, three utilized a randomized control design (Brijoux, Kricheldorff, Hüll, \& Bonfico, 2016; Glueckauf et al., 2007; Hicken et al., 2017), and one utilized a stepped wedge design (Paddick et al., 2017). Although many studies described 
Table 3: Summary of study characteristics

\begin{tabular}{|c|c|c|c|}
\hline Characteristics of Descriptive Studies & $n=45^{\circ}$ & Characteristics of Intervention/Evaluation Studies & $n=24$ \\
\hline Geographical Location (continent) & & Geographical Location (continent) & \\
\hline North America & 26 & North America & 13 \\
\hline Europe & 13 & Europe & 2 \\
\hline Australia & 4 & Australia & 5 \\
\hline Asia & 1 & Asia & 3 \\
\hline Africa & 1 & Africa & 1 \\
\hline Time Period & & Time Period & \\
\hline 1997-2001 & 5 & $1997-2001$ & 1 \\
\hline $2002-2006$ & 16 & $2002-2006$ & 6 \\
\hline 2007-2011 & 6 & $2007-2011$ & 3 \\
\hline 2012-2017 & 18 & 2012-2017 & 14 \\
\hline Methodology & & Methodology & \\
\hline Qualitative & 22 & Qualitative & 5 \\
\hline Quantitative & 14 & Quantitative & 13 \\
\hline Mixed methods & 9 & Mixed methods & 6 \\
\hline Rurality & & Rurality & \\
\hline Rural and urban groups & 9 & Rural and urban groups & 5 \\
\hline Rural and remote & 34 & Rural and remote & 17 \\
\hline Primarily rural & 2 & Primarily rural & 2 \\
\hline Participants & & Participants & \\
\hline People with dementia & 18 & People with dementia & 10 \\
\hline Caregivers & 31 & Caregivers & 17 \\
\hline Health or service providers ${ }^{\mathbf{b}}$ & 18 & Health or service providers & 5 \\
\hline $\begin{array}{l}\text { Other (e.g., community members, } \\
\text { clergy, educators) }\end{array}$ & 8 & $\begin{array}{l}\text { Other (e.g., community members, } \\
\text { clergy, educators) }\end{array}$ & 2 \\
\hline
\end{tabular}

a One article is represented in both columns, since its main foci pertained to both the assessment of educational needs and intervention evaluation.

b Includes everyone involved in service provision including frontline providers but also managers, directors of care, etc.

both education and support services, support services were more frequently addressed than education. Participants were primarily caregivers and people with dementia although many articles included health or service providers, and a minority involved other individuals including community members without dementia. Among participants with dementia, Alzheimer's disease was the most frequently reported diagnosis, and some studies exclusively recruited people with $\mathrm{Alz}$ heimer's and/or their caregivers (see Tables 4 and 5). When caregivers were included, the majority tended to be spouses/partners or daughters and daughters-in-law, with two studies focused specifically on sons (McDonnell \& Ryan, 2014; Sanders \& McFarland, 2002).

The degree to which sex and gender were considered in this body of literature (and associated findings) was of interest, in line with efforts to better incorporate sex and gender into neurodegeneration research (Tierney, Curtis, Chertkow, \& Rylett, 2017). Most authors reported the sex of participants. Consistent with the broader literature, the vast majority of caregivers studied were women, making up 61 per cent to 92 per cent of samples. Only one study (other than those focused on caregiving sons), from Australia, reported more male (10) than female (8) participants (Orpin, Stirling, Hetherington, \& Robinson, 2014). Most studies also reported a higher proportion of female compared to male participants with dementia, as would be expected based on the higher prevalence of dementia among women (Prince et al., 2015). Few studies (Arai, Sugiura, Miura, Washio, \& Kudo, 2000; Edelman, Kuhn, Fulton, \& Kyrouac, 2006; Forbes, Morgan, \& Janzen, 2006; Herron \& Rosenberg, 2017; Li, Kyrouac, McManus, Cranston, \& Hughes, 2012; McDonnell \& Ryan, 2014; Nordberg, von Strauss, Kåreholt, Johansson, \& Wimo, 2005; Sanders \& McFarland, 2002; von Kutzleben, Reuther, Dortmann, \& Holle, 2016) examined sex (biological status as male or female) or gender (the ways maleness or femaleness may be expressed through roles, behaviors, etc.) in relation to service needs, use, and barriers. Only one intervention study included sex as an independent variable (Tomkins \& Bell, 2009), and found that it did not significantly affect the intervention's impact on depression, overall service use, or support group use.

Education and support programs/interventions for people with dementia and their caregivers in rural areas were evaluated in 24 articles from Canada, Spain, the United States, Tanzania, Australia, Korea, Japan, and Germany (see Table 5). All evaluations indicated favorable outcomes on at least some of the indices measured, suggesting benefits to rural populations. Support interventions for people with dementia included music 


\begin{tabular}{|c|c|c|c|c|}
\hline $\begin{array}{l}\text { Author/s, Year, } \\
\text { Country }\end{array}$ & Study Purpose & Methodology and Characteristics of Sample & $\begin{array}{l}\text { Findings Related to Support and Education } \\
\text { Service Needs, Accessibility, and Use }\end{array}$ & $\begin{array}{l}\text { Barriers to Accessibility } \\
\text { and Use of Services }\end{array}$ \\
\hline $\begin{array}{l}\text { Andrews, M. E., Morgan, } \\
\text { D. G., \& Stewart, N. J. } \\
2010 \\
\text { Canada }\end{array}$ & $\begin{array}{l}\text { To explore dementia care from the } \\
\text { perspectives of registered nurses } \\
\text { (RNs) working in remote northern } \\
\text { communities }\end{array}$ & $\begin{array}{l}\text { Methodology: Qualitative } \\
\text { Sample population: } 14 \text { RNs working in remote } \\
\text { communities } \\
\text { Rurality: Rural and remote } \\
\text { Sex of health service providers (HSPs): } 13 \\
\text { female }\end{array}$ & $\begin{array}{l}\text { - Limited resources within communities } \\
\text { - Need for community and caregiver (CG) edu- } \\
\text { cation on dementia } \\
\text { - Lack of information for families on how to } \\
\text { support person/s with dementia (PWD) at home }\end{array}$ & $\begin{array}{l}\text { - Limited financial resources } \\
\text { - Cultural values emphasiz- } \\
\text { ing family } \\
\text { - Distribution of specialized } \\
\text { services }\end{array}$ \\
\hline $\begin{array}{l}\text { Arai, Y., Sugiura, M., } \\
\quad \text { Miura, H., Washio, M., } \\
\text { \& Kudo, K. } \\
2000 \\
\text { Japan }\end{array}$ & $\begin{array}{l}\text { To examine whether concern for others' } \\
\text { opinions influences the use of public } \\
\text { services by rural caregivers to cogni- } \\
\text { tively impaired older adults }\end{array}$ & $\begin{array}{l}\text { Methodology: Mixed methods } \\
\text { Sample population: } 70 \text { CGs of individuals with } \\
\text { cognitive impairment (CI) }(70 \% \text { with a formal } \\
\text { diagnosis of dementia) } \\
\text { Rurality: Rural and remote } \\
\text { Sex of CG: } 88.6 \% \text { female } \\
\text { Caregiving relationships: } \\
\text { Spouse/partner }=34.3 \% \\
\text { Child }=12.9 \% \\
\text { Daughter-in-law }=47.1 \% \\
\text { Other }=5.7 \% \\
\text { Sex of PWD: } 64.3 \% \text { female }\end{array}$ & $\begin{array}{l}\text { - Six public services were available and used by } \\
\text { the following percentage of participants: Home } \\
\text { help/housekeeping }(22.7 \%) \text {, respite care }(16 \%) \text {, } \\
\text { day care }(19.3 \%) \text {, home nurse visits }(28.7 \%) \text {, } \\
\text { bathing services }(12.6 \%) \text {, and meals on wheels } \\
(5.8 \%) \text {. } \\
\text { - More than a third of CGs (37\%) did not use any } \\
\text { services, with } 25.7 \% \text { using one, } 20 \% \text { using two, } \\
\text { and } 17.2 \% \text { using three or more. } \\
\text { - CGs were } 3 \text { times more likely to use services if } \\
\text { the PWD had severe dependency in activities of } \\
\text { daily living (ADL). }\end{array}$ & $\begin{array}{l}\text { - Concern for what others } \\
\text { would think/say } \\
\text { - Stigma around service use } \\
\text { - Worry that professionals } \\
\text { would judge their house or } \\
\text { caregiving negatively }\end{array}$ \\
\hline $\begin{array}{l}\text { Bédard, M., Koivuranta, } \\
\text { A., \& Stuckey, A. } \\
2004 \\
\text { Canada }\end{array}$ & $\begin{array}{l}\text { To explore potential differences } \\
\text { between rural and urban caregivers } \\
\text { in the health impacts from providing } \\
\text { care to PWD }\end{array}$ & $\begin{array}{l}\text { Methodology: Quantitative } \\
\text { Sample population: CGs of individuals with } \\
\text { Alzheimer's disease (AD) or other dementias ( } 20 \\
\text { rural, } 17 \text { urban) } \\
\text { Rurality: Rural and urban groups } \\
\text { Sex of CG: } \\
\text { Rural }=75 \% \text { female } \\
\text { Urban }=82 \% \text { female } \\
\text { Sex of PWD: } \\
\text { Rural }=60 \% \text { female } \\
\text { Urban }=47 \% \text { female } \\
\text { Caregiving relationships: } \\
\text { Spouse/partner }=75 \% \text { rural } \\
\text { Spouse/partner }=41 \% \text { urban }\end{array}$ & $\begin{array}{l}\text { - Formal support services were reported to be } \\
\text { available by } 35 \% \text { of the rural CGs, compared to } \\
88 \% \text { of urban CGs. } \\
\text { - Most ( } 85 \% \text { ) rural CGs received only informal } \\
\text { help, compared to } 33 \% \text { of urban CGs, but rural } \\
\text { CGs reported more hours of support overall. }\end{array}$ & None reported \\
\hline $\begin{array}{l}\text { Buettner, L. L., \& } \\
\quad \text { Langrish, S. } \\
2001 \\
\text { United States }\end{array}$ & $\begin{array}{l}\text { To assess educational and support } \\
\text { needs of family caregivers of older } \\
\text { adults with probable } A D \text { in rural and } \\
\text { urban settings }\end{array}$ & $\begin{array}{l}\text { Methodology: Quantitative } \\
\text { Sample population: } 76 \text { CGs of persons with } \\
\text { probable AD ( } 31 \text { rural, } 45 \text { urban) } \\
\text { Rurality: Rural and urban groups } \\
\text { Sex of CGs: } \\
\text { Rural }=71 \% \text { female } \\
\text { Urban }=71.1 \% \text { female } \\
\text { Sex of PWD: } \\
\text { Rural }=67.7 \% \text { female } \\
\text { Urban }=80 \% \text { female } \\
\text { Dementia diagnoses: Probable AD }\end{array}$ & $\begin{array}{l}\text { - Rural CGs were most interested in recreation } \\
\text { support, in-home sitters, and regular paid help. } \\
\text { - Rural CGs had a high level of interest in learning } \\
\text { new coping strategies, especially in relation to } \\
\text { activities for the PWD and dealing with restless/ } \\
\text { agitated and clingy behaviours. } \\
\text { - Few rural CGs participated in support groups or } \\
\text { counselling ( }(14.3 \% \text { and } 10.3 \% \text { respectively), and } \\
\text { there was little interest in these supports. } \\
\text { - Over half of rural CGs took part in Alzheimer's } \\
\text { education activities (lower for urban CGs); no }\end{array}$ & None reported \\
\hline
\end{tabular}


Author/s, Year,

Country

Country

Year,

Study Purpose

Methodology and Characteristics of Sample

urban/rural differences in participation in support groups, counselling, legal or financial cation.

- More rural than urban CGs needed help with recreation and wanted to learn about rec services and how to occupy the PWD.

\begin{tabular}{ll}
\hline Burholt, V., Wenger, C., & To explore and compare formal help \\
\& Scott, A. & and services received by people over \\
1997 & 75 with dementia to those without \\
United Kingdom & dementia
\end{tabular}

\section{Methodology: Quantitative}

Sample population: 55 rural PWD (405 persons

- Rural PWD had low levels of contact (similar to without dementia [PND]) and 36 urban PWD (58 PND)

Rurality: Rural and urban groups Sex of PWD:

Rural $=75 \%$ female

Urban $=51 \%$ female

urban) with social care services: social worker

$(20 \%)$, voluntary helper (9\%), occupational or

- Rural residents had home visits from local authority home help (31\%), social workers

$(14 \%)$, meals on wheels $(11 \%)$, voluntary helper $(8 \%)$, respite night sitters $(6 \%)$, and private home

\begin{tabular}{|c|c|c|c|c|}
\hline $\begin{array}{l}\text { Burton, R., O'Connell, } \\
\text { M. E., \& Morgan, D. G. } \\
2016 \\
\text { Canada }\end{array}$ & $\begin{array}{l}\text { To explore interest and goals for cog- } \\
\text { nitive rehabilitation delivered by } \\
\text { videoconference to rural individuals } \\
\text { with mild cognitive impairment (MCl) } \\
\text { or dementia }\end{array}$ & $\begin{array}{l}\text { Methodology: Mixed methods } \\
\text { Sample population: } 12 \text { rural patients and } 13 \\
\text { caregivers who attended a memory clinic } \\
\text { Rurality: Rural and remote } \\
\text { Dementia diagnoses: } M C l(5), A D(8), A D \text { or } \\
\text { vascular dementia (VaD) (2) }\end{array}$ & $\begin{array}{l}\text { - All participants interested in cognitive rehabili- } \\
\text { tation to work on daily goals preferred video- } \\
\text { conferencing delivery using telehealth. } \\
\text { - Participants identified the need for education } \\
\text { about available services and what to do as } \\
\text { dementia progresses. }\end{array}$ & None reported \\
\hline $\begin{array}{l}\text { Clarke, C. L., \& Bailey, C. } \\
2016 \\
\text { United Kingdom }\end{array}$ & $\begin{array}{l}\text { To explore experiences of living with } \\
\text { dementia within rural and semi-urban } \\
\text { communities }\end{array}$ & $\begin{array}{l}\text { Methodology: Qualitative } \\
\text { Sample population: } 13 \text { PWD, } 12 \text { CGs, and } 6 \\
\text { stakeholders working in the public and charit- } \\
\text { able sectors } \\
\text { Rurality: Rural and remote } \\
\text { Sex of PWD: } 54 \% \text { female }\end{array}$ & $\begin{array}{l}\text { - Participants identified availability of and access } \\
\text { to services as an issue. } \\
\text { - Participants were sometimes reluctant to seek } \\
\text { out information. }\end{array}$ & $\begin{array}{l}\text { - Not relating to services } \\
\text { - Affordability } \\
\text { - Perceived unsuitability } \\
\text { - Rural independence } \\
\text { - Not wanting to "bother" } \\
\text { others }\end{array}$ \\
\hline $\begin{array}{l}\text { Coogle, C. L. } \\
2002 \\
\text { United States }^{\mathbf{b}}\end{array}$ & $\begin{array}{l}\text { To describe the development and } \\
\text { evaluation of a dementia educational } \\
\text { intervention for African American } \\
\text { and rural families }\end{array}$ & $\begin{array}{l}\text { Methodology: Quantitative } \\
\text { Sample population (needs portion of the } \\
\text { study): } 15 \text { rural and } 14 \text { urban experts includ- } \\
\text { ing people from higher education, the local } \\
\text { Alzheimer's Association chapters, service pro- } \\
\text { viders, clergical association groups, and family } \\
\text { CGs } \\
\text { Rurality: Rural and urban groups }\end{array}$ & $\begin{array}{l}\text { - Rural education needs (from most to least } \\
\text { important): Understanding and treating AD, } \\
\text { patient behaviours and interventions, impact on } \\
\text { CGs and the family, interventions that CGs can } \\
\text { use, resources for CGs, legal/financial/patient } \\
\text { competency, and placement options/continuum } \\
\text { of care } \\
\text { - Urban education needs (from most to least } \\
\text { important): Emotional and psychological con- } \\
\text { sequences of caregiving, CG supports, clinical } \\
\text { information, safety, and legal/ financial issues }\end{array}$ & None reported \\
\hline
\end{tabular}

able sectors
Findings Related to Support and Education Service Needs, Accessibility, and Use planning, case management, or home modifiphysiotherapist (4\%). help (8\%).

- No significant differences in home visits found between rural and urban (PWD and PND).

- More rural than urban PWD received a package of 5 or more social care services.

Barriers to Accessibility and Use of Services ${ }^{a}$

None reported

ing to services

- Not wanting to "bother"

Methodology: Quantitative

study) 15 rural and 14 urban experts includ-

ing people from higher education, the local

Alzheimer's Association chapters, service pro-

CGs 


\begin{tabular}{|c|c|c|c|c|}
\hline $\begin{array}{l}\text { Author/s, Year, } \\
\text { Country }\end{array}$ & Study Purpose & Methodology and Characteristics of Sample & $\begin{array}{l}\text { Findings Related to Support and Education } \\
\text { Service Needs, Accessibility, and Use }\end{array}$ & $\begin{array}{l}\text { Barriers to Accessibility } \\
\text { and Use of Services }\end{array}$ \\
\hline $\begin{array}{l}\text { Dal Bello-Haas, V. P. M., } \\
\text { Cammer, A., Morgan, } \\
\text { D., Stewart, N., \& } \\
\text { Kosteniuk, J. } \\
2014 a \\
\text { Canada }\end{array}$ & $\begin{array}{l}\text { To describe formal and informal rural } \\
\text { dementia caregivers' perceptions of } \\
\text { caregiving challenges and needs }\end{array}$ & $\begin{array}{l}\text { Methodology: Mixed methods } \\
\text { Sample population: } \\
\text { Consultation meetings = health service providers } \\
\text { (HSPs) } \\
\text { Telephone and mail questionnaires = } 33 \text { phys- } \\
\text { icians, } 28 \mathrm{HSP} \text { in management or administration } \\
\text { positions, and } 33 \text { direct HSP } \\
\text { Referral letters }=250 \text { physicians } \\
\text { Clinic questionnaire }=151 \mathrm{CGs} \\
\text { Rurality: } \text { Rural and remote }\end{array}$ & $\begin{array}{l}\text { - Only } 48 \% \text { of physicians and } 19.3 \% \text { of other } \\
\text { HSPs reported that available support services } \\
\text { for PWD and CGs were adequate. } \\
\text { - One third of physicians reported that additional } \\
\text { services like support services and counselling } \\
\text { were needed. } \\
\text { - Participants identified the following support } \\
\text { needs: respite facilities, day programs, home } \\
\text { care, programs for early-stage PWD, support } \\
\text { groups, and social work support. }\end{array}$ & None reported \\
\hline $\begin{array}{l}\text { Di Gregorio, D., } \\
\text { Ferguson, S., \& } \\
\text { Wiersma, E. } \\
2015 \\
\text { Canada }\end{array}$ & $\begin{array}{l}\text { To explore the experiences of rural } \\
\text { people living with dementia, their } \\
\text { caregivers, health/ service providers, } \\
\text { and community members }\end{array}$ & $\begin{array}{l}\text { Methodology: Qualitative } \\
\text { Sample population: } 37 \text { health and social ser- } \\
\text { vice providers, } 15 \text { CGs, } 2 \text { PWD, and } 17 \text { other } \\
\text { community members (neighbours, friends, } \\
\text { volunteers, business owners, and clergy) } \\
\text { Rurality: Rural and remote }\end{array}$ & $\begin{array}{l}\text { - Participants reported low availability of local } \\
\text { organizations providing dementia-related edu- } \\
\text { cation and services } \\
\text { - Participants reported the need for more general } \\
\text { information about dementia, and the need for } \\
\text { education on formal services and programs }\end{array}$ & $\begin{array}{l}\text { - Geographical barriers } \\
\text { - Lack of awareness of sup- } \\
\text { port services, and how to } \\
\text { use them } \\
\text { - Low visibility of organiza- } \\
\text { tions providing dementia- } \\
\text { related education and } \\
\text { services within rural north- } \\
\text { ern communities }\end{array}$ \\
\hline $\begin{array}{l}\text { Edelman, P., Kuhn, D., } \\
\text { Fulton, B. R., \& } \\
\text { Kyrouac, G. A. } \\
2006 \\
\text { United States }\end{array}$ & $\begin{array}{l}\text { To explore the information and service } \\
\text { needs of people with } A D \text { and their } \\
\text { caregivers living in rural areas }\end{array}$ & $\begin{array}{l}\text { Methodology: Quantitative } \\
\text { Sample population: } 100 \text { PWD and their CGs } \\
\text { living in rural areas }(n=200) \\
\text { Rurality: Rural and remote } \\
\text { Sex of CG: } 61 \% \text { female } \\
\text { Caregiving relationships: } \\
\text { Spouse/partner }=44 \% \\
\text { Child/in-law }=46 \% \\
\text { Other }=10 \% \\
\text { Sex of PWD: } 70 \% \text { female } \\
\text { Dementia diagnoses: AD }\end{array}$ & $\begin{array}{l}\text { - PWD and CGs often expressed different needs/ } \\
\text { priorities for information and services. } \\
\text { - More than } 90 \% \text { of CGs wanted more informa- } \\
\text { tion on AD, different treatment options, coping } \\
\text { with challenging symptoms, meaningful activ- } \\
\text { ities, dealing with family and friends, and } \\
\text { improving communication. } \\
\text { - Needs expressed by over } 70 \% \text { of CGs (fewer } \\
\text { PWD) included support coping with depression } \\
\text { and anxiety, support paying for services, and } \\
\text { information on: legal/financial planning and } \\
\text { long-term care (LTC), decisions about driving, } \\
\text { adjusting to increased or decreased responsi- } \\
\text { bilities, and finding services and community } \\
\text { resources. } \\
\text { - Fewer PWD expressed needs; frequent needs } \\
\text { were information on AD (70\%), approved and } \\
\text { experimental drug treatments (63\% and } 52 \%) \text {, } \\
\text { meaningful activities ( } 49 \%) \text {, and coping with } \\
\text { challenging symptoms (49\%). } \\
\text { - } 81 \% \text { of CGs and } 45 \% \text { of PWD were interested } \\
\text { in support groups. }\end{array}$ & None reported \\
\hline
\end{tabular}




\section{Author/s, Year,}

Country

2015

Australia
Ervin, K., \& Reid, C
Study Purpose

To explore the use of community and dementia-specific services by rural dementia caregivers

\section{Methodology and Characteristics of Sample}

Methodology: Quantitative

Sample population: 39 rural CGs to PWD

Rurality: Rural and remote

Sex of CG: $77 \%$ female

Caregiving relationships:

Spouse/ partner $=46 \%$

Daughter $=33 \%$

Other (son, nephew, niece, sister, friend) $=21 \%$

Sex of PWD: $54 \%$ female

Dementia diagnoses:

$\mathrm{AD}=46 \%$; other (Parkinson's disease, vascular

dementia, cerebral amyloidosis) $=10 \%$

unknown $=43 \%$
Findings Related to Support and Education

Service Needs, Accessibility, and

- CGs used 2 to 12 of the support services

$(M=6.8)$.

- The most commonly used services were Aged

Care Assessment (84\%), printed information on dementia or services $(61 \%)$, household help $(51 \%)$, community nursing (48\%), financial compensation (e.g., CG pension; 46\%), legal administration or guardianship (46\%), and respite in a facility $(41 \%)$ or at home $(38 \%)$.

- Few respondents refused offered services, suggesting care is generally acceptable.

- Other than specialized holidays, over $80 \%$ of

CGs reported knowledge of service availability.

- Less than half of respondents (20-46\%) with selfreported moderate to severe depression, anxiety, and stress used services that could be helpful; support groups were most used followed by respite care.

Forbes, D. et al.

To explore knowledge sharing among health care providers, caregivers, and people with dementia in a rural First Nations community

- CG initially required information about dementia symptoms and trajectory, and how to determine decision-making competency.

- In later stages CG requested information on

\section{Methodology: Qualitative}

Sample population: Two First Nations dementia care networks, which included 2 PWD, 3 CGs, and 2 HSPs

Rurality: Rural and remote

Sex of PWD: $100 \%$ female

Sex of CG: $66.6 \%$ female

Dementia diagnoses: $A D$ end-of-life decisions and LTC.

- CG sought information from HSP, the First Link program, and knowledgeable family members.

- Stigma related to First Nation communities

limited availability of services and information.

- Respite was not available beyond a few hours and was reported as a need.

- PWD needed better counseling support.

Forbes, D. A. et al.
2012

Canada
To assess information needs, how information is accessed, and barriers and facilitators of knowledge

exchange between community-based HSP, CG, and PWD

\section{Methodology: Qualitative}

Sample population: 5 PWD, 14 CGs, and 14 community-based HSPs living/practicing in rural areas

Rurality: Rural and remote

Sex of CG: $78.6 \%$ female

Sex of PWD: $60 \%$ male

Sex of HSP: $65 \%$ female

Dementia diagnoses: $A D$
- PWD in 6/9 care networks used home care services, 4 used respite day programs, and 2 used overnight respite.

- Information was sought from family/friends, local organizations, Internet, and HSP.

- Information needs varied with dementia stage.

- Initial information needs of PWD and CG included management/treatment, potential safety issues, and home care/support options. - As dementia progressed, CG needed information on navigating the health system, advocating for the PWD, legal issues, driving competency, home care services, and respite.

- Eventually CG wanted information on LTC.

- HSP felt that end-of-life care was an important information need for CG.
Barriers to Accessibility and Use of Services ${ }^{\circ}$

None reported

- Pilot/unsustainable programming

- PWD lack of awareness/ denial of symptoms

- Stigma a barrier to attending support groups

- Complexity of presented

information

- Perceived unsuitability

- PWD resistance

- Perceived unsuitability

- Lack of transportation

services

- Geographical distance

- Not wanting to impose

- LTC and end-of-life info threatening to $C G$

- Valuing independence

- Rationing resources

- Stigma

- CG burnout a barrier to

seeking info

- Denial of PWD

- Limited time with HSP 


\begin{tabular}{|c|c|c|c|c|}
\hline $\begin{array}{l}\text { Forbes, D., Ward- } \\
\text { Griffin, C., Kloseck, } \\
\text { M., Mendelsohn, M., } \\
\text { St.-Amant, O., } \\
\text { DeForge, R., \& Clark, K. } \\
2011 \\
\text { Canada }\end{array}$ & $\begin{array}{l}\text { To explore rural dementia care from the } \\
\text { perspectives of people with dementia, } \\
\text { home care providers, and family } \\
\text { caregivers, using an in/exclusion lens }\end{array}$ & $\begin{array}{l}\text { Methodology: Qualitative } \\
\text { Sample population: Three dementia care net- } \\
\text { works including } 3 \text { PWD, } 14 \text { family members/ } \\
\text { CGs, and } 3 \text { HSPs } \\
\text { Rurality: Rural and remote } \\
\text { Sex of PWD: } 66.6 \% \text { female }\end{array}$ & $\begin{array}{l}\text { - Family members were often unaware of incon- } \\
\text { tinence products and approaches that would be } \\
\text { helpful for this issue. } \\
\text { - Families had limited choice in the type, amount, } \\
\text { and provider of home care services. }\end{array}$ & $\begin{array}{l}\text { - Lack of anonymity } \\
\text { - Stigma }\end{array}$ \\
\hline $\begin{array}{l}\text { Glueckauf, R. L. et al. } \\
2005 \\
\text { United States }\end{array}$ & $\begin{array}{l}\text { To explore the education and support } \\
\text { needs of rural dementia caregivers }\end{array}$ & $\begin{array}{l}\text { Methodology: Qualitative } \\
\text { Sample population: } 12 \text { rural HSPs, } 12 \text { African } \\
\text { American pastors, church elders, community } \\
\text { leaders, and CGs, and } 9 \text { non-Hispanic White } \\
\text { pastors, church elders, community leaders, and } \\
\text { CGs } \\
\text { Rurality: Rural and remote }\end{array}$ & $\begin{array}{l}\text { - Information about and referrals to support ser- } \\
\text { vices are needed. } \\
\text { - CGs require information on dementia charac- } \\
\text { teristics, diagnosis, and treatment. } \\
\text { - CGs and PWD require skill sets including } \\
\text { effective coping techniques, behavioral man- } \\
\text { agement skills, financial planning ability, and the } \\
\text { capacity to complete advance directives. }\end{array}$ & $\begin{array}{l}\text { - Lack of knowledge about } \\
\text { support services } \\
\text { - Stigma } \\
\text { - Reluctance to seek help } \\
\text { outside of family } \\
\text { - Desire to protect privacy }\end{array}$ \\
\hline $\begin{array}{l}\text { Gurayah, T. } \\
2015 \\
\text { South Africa }\end{array}$ & $\begin{array}{l}\text { To explore the experiences of care- } \\
\text { givers to people with dementia in } \\
\text { rural South Africa }\end{array}$ & $\begin{array}{l}\text { Methodology: Qualitative } \\
\text { Sample population: } 5 \text { primary CGs to persons } \\
\text { with dementia } \\
\text { Rurality: Rural and remote } \\
\text { Sex of CG: } 80 \% \text { female } \\
\text { Caregiving relationships: } \\
\text { Spouse/partner }=20 \% \\
\text { Daughter }=60 \% \\
\text { Son }=20 \%\end{array}$ & $\begin{array}{l}\text { - CG needs included education and training, } \\
\text { information on local services, and referrals to } \\
\text { support services for CGs who are struggling. }\end{array}$ & None reported \\
\hline $\begin{array}{l}\text { Herron, R. V., \& } \\
\quad \text { Rosenberg, M. W. } \\
2017 \\
\text { Canada }\end{array}$ & $\begin{array}{l}\text { To explore the social and spatial inter- } \\
\text { actions of rural people with dementia, } \\
\text { and understand their perceptions of } \\
\text { services }\end{array}$ & $\begin{array}{l}\text { Methodology: Qualitative } \\
\text { Sample population: } 46 \text { PWD and } 43 \text { CGs } \\
\text { Rurality: Rural and remote } \\
\text { Sex of PWD: } 57 \% \text { male } \\
\text { Caregiving relationships: }\end{array}$ & $\begin{array}{l}\text { - There was a lack of early stage support. } \\
\text { - Participants who were single and lived alone } \\
\text { made use of more services, earlier. } \\
\text { - A memory café was an appreciated support. }\end{array}$ & $\begin{array}{l}\text { - Culture of independence } \\
\text { and contribution } \\
\text { - Lack of perceived accept- } \\
\text { ability and suitability of } \\
\text { supports }\end{array}$ \\
\hline
\end{tabular}

gy and Characteristics of Sample

Findings Related to Support and Education Service Needs, Accessibility, and Use

\begin{tabular}{ll}
\hline Forbes, D., Morgan, D., & To explore use of services by older \\
\& Janzen, B. & Canadians with dementia, and the \\
2006 & impact of place (rural/urban) on
\end{tabular}

service use age 50 , including 313 with dementia $(81$ rural

- In order of frequency, PWD in rural areas received personal care, housework help, meal prep assistance, housework, respite, nursing, and visits by other HSPs. PWD in urban areas

\section{Methodology: Quantitative}

Sample population: 49,995 Canadians over and 232 urban residents). Population estimates were derived.

Rurality: Rural and urban groups

Sex of PWD:

Rural $=53 \%$ female

Urban $=51 \%$ female received (in order of frequency) personal care nursing, housework, respite, visits by HSPs, meal

- 39\% of rural respondents used home care, and only $4.8 \%$ attended a self-help group; this was similar to urban respondents.

- Unique reasons for the unmet needs of rural

$\mathrm{CGs}$, and $3 \mathrm{HSPs}$

Rurality: Rural and remote

Methodology: Qualitative

ample population: 12 rural HSPs, 12 Africa pastors, church elders, community leaders, and

logy: Qualitative

with dementia

Methodology: Qualitative

Rurality: Rural and remote

Caregiving relationships: prep, and shopping assistance. participants included lack of time, available care, and knowledge of where to go.

Femount,

Barriers to Accessibility and Use of Services ${ }^{a}$

- Lack of time

- Lack of knowledge of ser-

- Perceptions that services

would be inadequate

- Affordability

-Waiting time

vices are needed.

agement skills, financial planning ability, and the

Cormation on local services, and referrals to

- Stigma

seek help

outside of family

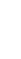

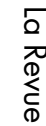




\begin{tabular}{lr}
\hline $\begin{array}{l}\text { Author/s, Year, } \\
\text { Country }\end{array}$ & Study Purpose \\
\hline & \\
& \\
& \\
\hline Herron, R. V., & To explore the challenges associated \\
Rosenberg, M. W., \& & with rural dementia service delivery \\
Sinner, M. W. & \\
2016 & \\
Canada &
\end{tabular}

Methodology and Characteristics of Sample

Spouse/ partner $=91 \%$

Daughter $=5 \%$

Son $=2 \%$

Sister $=2 \%$

Findings Related to Support and Education Service Needs, Accessibility, and Use

- Information on dementia and supports was accessed through the Alzheimer's Society, sometimes through referral.

- Men refused support services such as day programs more often than women.

Methodology: Mixed methods

Sample population: An Alzheimer's Society service provider from 20 chapters, 46 PWD, and 43 CGs

Rurality: Rural and remote, with organizations serving rural and urban areas

- All chapters had CG and PWD support groups, information, education, and referrals. 9 had First Link programs and 8 had volunteer companion services. Few had counselling (3), in-home respite (4), day programs (5), rec/leisure therapy (3), transportation (2), and specialized programs. - Service providers reported fewer services offered by other organizations in rural areas. - Rural service users reported little early stage support and insufficient support overall.

- Rural clients used fewer overall and in-office services compared to urban clients, and more one-on-one home visits and transportation. home and an outlet outside of the home.

\begin{tabular}{ll}
\hline Innes, A., Blackstock, K., & To explore the views of rural individuals \\
Mason, A., Smith, A., & with dementia and caregivers on \\
\& Cox, S. & dementia-related service provision \\
2005 &
\end{tabular}

Scotland

- 35 of 45 participants reported gaps in available services.

- 26 refused offered services because they were perceived as unsuitable.

- 13 participants had unmet respite needs (e.g.,
- Rural support groups were underutilized.

- Participants reported a need for more help at
Methodology: Qualitative

Sample population: 15 service users with

dementia and $30 \mathrm{CGs}$

Rurality: Rural and remote

Sex of CG: $73 \%$ female

Sex of care recipient: $52 \%$ female

Sex of service users with dementia: $73 \%$ female
Barriers to Accessibility and Use of Services ${ }^{a}$

\section{- Stigma}

- Aversion to group support

- Transportation

- Distance

- Stigma

- Denial of the PWD

- Lack of respite services

- Lack of program continuity/availability

- Lack of knowledge of services

- Financial

- Educational material not appropriate for all users

- Reluctance to use group supports weekends or home-based care).

- Home care provision was inadequate in the more remote areas.

- 10 CGs reported a lack of support, including early/timely information.

- All but one of the 45 participants mentioned positive aspects of the services they or the PWD was receiving.

\begin{tabular}{ll}
\hline Innes, A., Cox, S., Smith, & To explore the views of service pro- \\
A., \& Mason, A. & viders on service provision in rural \\
2006 & areas, and how barriers can be \\
Scotland & overcome
\end{tabular}

\section{Methodology: Mixed methods}

Sample population: Service providers from 86 organizations, from the voluntary sector (34\%), local authorities $(29 \%)$, health trusts $(19 \%)$, private sector $(12 \%)$, health boards $(4 \%)$, and housing associations (4\%)

Rurality: Rural and remote
- Almost $75 \%$ of service providers provided transportation, either through their organization, another organization, or a combination of services.

- Outreach or local services had been developed by $26 \%$, and in-home services by $14 \%$.

- Services were available across all regions and degrees of rurality.
- Transportation

- Lack of perceived acceptability and suitability

- Effort getting the PWD ready for day care - Desire to protect privacy

- Desire to stay at home

- CG beliefs and guilt

- Distress to service users

\section{- Geographical/travel}

- Transportation costs

- Fee-for-access services - Suitability vices

- Stigma
- Lack of awareness of ser-

-




\begin{tabular}{|c|c|c|c|c|}
\hline $\begin{array}{l}\text { Author/s, Year, } \\
\text { Country }\end{array}$ & Study Purpose & Methodology and Characteristics of Sample & $\begin{array}{l}\text { Findings Related to Support and Education } \\
\text { Service Needs, Accessibility, and Use }\end{array}$ & $\begin{array}{l}\text { Barriers to Accessibility } \\
\text { and Use of Services }\end{array}$ \\
\hline $\begin{array}{l}\text { Innes, A., Sherlock, K., \& } \\
\text { Cox, S. } \\
2003 \\
\text { Scotland }\end{array}$ & $\begin{array}{l}\text { To explore service provision across rural } \\
\text { and remote Scotland from the per- } \\
\text { spectives of people with dementia }\end{array}$ & $\begin{array}{l}\text { Methodology: Qualitative } \\
\text { Sample population: } 17 \text { PWD living in rural } \\
\text { areas } \\
\text { Rurality: Rural and remote } \\
\text { Sex of PWD: } 64.7 \% \text { female }\end{array}$ & $\begin{array}{l}\text { - Support services accessed by participants were } \\
\text { day care (10), care worker home visits (10), } \\
\text { personal coping support (8), transportation to } \\
\text { services (8), meals on wheels (4), home modifi- } \\
\text { cation (4), personal care (2), support group (2), } \\
\text { and temporary respite care (2). } \\
\text { - Participants reported gaps in the range and } \\
\text { frequency of services available locally. }\end{array}$ & $\begin{array}{l}\text { - Geographical/travel dis- } \\
\text { tances } \\
\text { - Format of services per- } \\
\text { ceived as inappropriate }\end{array}$ \\
\hline $\begin{array}{l}\text { Innes, A., Szymczynska, P., } \\
\quad \text { \& Stark, C. } \\
2014 \\
\text { Scotland }\end{array}$ & $\begin{array}{l}\text { To explore perceptions of diagnosis and } \\
\text { post-diagnosis support offered to } \\
\text { people with dementia and their fam- } \\
\text { ilies }\end{array}$ & $\begin{array}{l}\text { Methodology: Qualitative } \\
\text { Sample population: Six PWD and } 12 \text { CGs in } \\
\quad \text { rural Scotland } \\
\text { Rurality: Rural and remote } \\
\text { Sex of CG: } 91.7 \% \text { female } \\
\text { Caregiving relationships: } \\
\text { Spouse/partner }=66.7 \% \\
\text { Child }=25 \% \\
\text { Sibling }=8.3 \% \\
\text { Sex of PWD: } 50 \% \text { female }\end{array}$ & $\begin{array}{l}\text { - CG support groups were helpful when avail- } \\
\text { able, and most CG received support on a } \\
\text { regular basis. } \\
\text { - Participants were happy with services provided } \\
\text { but needed more help than was available (e.g., } \\
\text { more respite time). } \\
\text { - PWD and CG wanted more information about } \\
\text { care and supports, at diagnosis. } \\
\text { - Participants wanted information about how to } \\
\text { prepare for the future, how to manage symp- } \\
\text { toms and stages, and available supports. }\end{array}$ & $\begin{array}{l}\text { - Perceptions of services as } \\
\text { inappropriate } \\
\text { - Service refusal } \\
\text { - Geographical/travel dis- } \\
\text { tances } \\
\text { - Difficulty gaining access } \\
\text { - Respite } \\
\text { - CG reluctance to leave } \\
\text { PWD with someone else } \\
\text { - Written information not } \\
\text { appropriate for all users }\end{array}$ \\
\hline $\begin{array}{l}\text { Kelsey, S. G., \& Laditka, } \\
\text { S. B. } \\
2006 \\
\text { United States }\end{array}$ & $\begin{array}{l}\text { To assess how the practices of AD day } \\
\text { programs in rural South Carolina } \\
\text { compare to best practices }\end{array}$ & $\begin{array}{l}\text { Methodology: Mixed methods } \\
\text { Sample population: Directors at } 21 \text { adult day } \\
\text { program sites with services for people with } A D \\
\text { Rurality: Primarily rural }\end{array}$ & $\begin{array}{l}\text { - Programs were limited in hours and days open } \\
\text { ( } M \text { days = 2.05, range 1-5). } \\
\text { - A variety of activities for PWD were offered, } \\
\text { and programs often provided CG support } \\
\text { groups }(57 \%) \text {, phone or in-person counseling } \\
(61.9 \%), C G \text { information ( } 95 \%) \text {, and CG edu- } \\
\text { cation ( } 81 \%) .23 .8 \% \text { had an in-home education } \\
\text { program (including crisis intervention and sup- } \\
\text { port services information. } \\
\text { - Most programs incorporated best practices. }\end{array}$ & $\begin{array}{l}\text { - Incontinence a possible } \\
\text { eligibility barrier }\end{array}$ \\
\hline $\begin{array}{l}\text { Kosloski, K., Schaefer, } \\
\text { J. P., Allwardt, D., } \\
\text { Montgomery, J. V., \& } \\
\text { Karner, T. X. } \\
2002 \\
\text { United States }\end{array}$ & $\begin{array}{l}\text { To explore how culture influences the } \\
\text { use of respite services }\end{array}$ & $\begin{array}{l}\text { Methodology: Quantitative } \\
\text { Sample population: } 315 \text { CGs who had utilized } \\
\text { in-home respite or adult day care }(47 \% \text { rural, } \\
53 \% \text { urban) } \\
\text { Rurality: Rural and urban groups } \\
\text { Sex of CG: } 73 \% \text { female } \\
\text { Dementia diagnoses: AD }\end{array}$ & $\begin{array}{l}\text { - Urban users used more average monthly hours } \\
\text { of day care and respite (46.2) than rural users } \\
\text { (35.3). } \\
\text { - Respect for elders was positively related to use; } \\
\text { urban participants reported more respect. } \\
\text { - Geographic location did not predict respite use } \\
\text { above variables representing attitudes about } \\
\text { caregiving and evaluations of service delivery. }\end{array}$ & None reported \\
\hline $\begin{array}{l}\text { von Kutzleben, M., } \\
\text { Reuther, S., Dortmann, } \\
\text { O., \& Holle, B. } \\
2016 \\
\text { Germany }\end{array}$ & $\begin{array}{l}\text { To explore home-based care, use of } \\
\text { formal services, and factors associ- } \\
\text { ated with stability of care from CG' } \\
\text { perspectives }\end{array}$ & $\begin{array}{l}\text { Methodology: Quantitative } \\
\text { Sample population: } 84 \text { CGs of persons with } \\
\text { dementia } \\
\text { Rurality: Rural and remote } \\
\text { Sex of CG: } 79.5 \% \text { female }\end{array}$ & $\begin{array}{l}\text { - Only } 15.5 \% \text { of CG did not use formal services. } \\
\text { The most frequently used services were home } \\
\text { care nursing (53\%), day care }(49.4 \%) \text {, and res- } \\
\text { pite }(29.6 \%) \text {. Less-used services were Meals on }\end{array}$ & None reported \\
\hline
\end{tabular}

PWD and CG wanted more information about care and supports, at diagnosis. appropriate for all users

2006 cation (81\%). $23.8 \%$ had an in-home education (including crisis intervention and sup-

Respect for elders was positively related to use urban participants reported more respect.

ove caregiving and evaluations of service delivery.

The most frequently used services were home Sex of CG: $79.5 \%$ female 
Table 4: Continued

\begin{tabular}{|c|c|c|c|c|}
\hline \multirow[t]{2}{*}{$\begin{array}{l}\text { Author/s, Year, } \\
\text { Country }\end{array}$} & \multirow[t]{2}{*}{ Study Purpose } & Methodology and Characteristics of Sample & $\begin{array}{l}\text { Findings Related to Support and Education } \\
\text { Service Needs, Accessibility, and Use }\end{array}$ & $\begin{array}{l}\text { Barriers to Accessibility } \\
\text { and Use of Services }\end{array}$ \\
\hline & & $\begin{array}{l}\text { Caregiving relationships: } \\
\text { Spouse/partner }=27.4 \% \\
\text { Child }=48.8 \% \\
\text { Child-in-law }=9.5 \% \\
\text { Neighbour }=2.4 \% \\
\text { Other }=4.8 \% \\
\text { Sex of PWD: } 60.2 \% \text { female }\end{array}$ & $\begin{array}{l}\text { Wheels }(6.8 \%) \text {, companion home visits }(7.2 \%) \text {, } \\
\text { and social care groups }(2.4 \%) \text {. } \\
\text { - Most CGs }(54.5 \%) \text { felt their situation was func- } \\
\text { tional but would require future help; } 32.9 \% \text { did } \\
\text { not foresee needing more help; and } 11.4 \% \\
\text { reported the care situation as malfunctioning or } \\
\text { extremely unstable. }\end{array}$ & \\
\hline $\begin{array}{l}\text { McDonald, A., \& } \\
\text { Heath, B. } \\
2009 \\
\text { United Kingdom }\end{array}$ & $\begin{array}{l}\text { To examine rural dementia-related ser- } \\
\text { vices across different sectors and how } \\
\text { local needs are being addressed in } \\
\text { relation to national policy }\end{array}$ & $\begin{array}{l}\text { Methodology: Qualitative } \\
\text { Sample population: Strategic managers, } \\
\text { frontline managers and service providers, } \\
\text { PWD, and CGs } \\
\text { Rurality: Rural and remote }\end{array}$ & $\begin{array}{l}\text { - Service provision was patchy and often devel- } \\
\text { oped based on local need, on the initiative of } \\
\text { key individuals or organizations } \\
\text { - CGs reported the need for more consistent, } \\
\text { flexible, coordinated services } \\
\text { - Participants reported the needs of people with } \\
\text { young onset dementia and those from minority } \\
\text { ethnic groups were largely unmet } \\
\text { - CGs needed information and education that } \\
\text { was empathetic and provided "at their pace". }\end{array}$ & Financial barriers \\
\hline
\end{tabular}

H., Kyrouac, G.,

met service needs of rural lder adults with $A D$, and factors

Hughes, $\mathrm{S}$.

2012

United States ex of CG: $78.9 \%$ female

Caregiving relationships:

Child = 29.4\%

Other $=5.5 \%$

Sex of PWD. $51.4 \%$ male

.




\begin{tabular}{|c|c|c|c|c|}
\hline $\begin{array}{l}\text { Author/s, Year, } \\
\text { Country }\end{array}$ & Study Purpose & Methodology and Characteristics of Sample & $\begin{array}{l}\text { Findings Related to Support and Education } \\
\text { Service Needs, Accessibility, and Use }\end{array}$ & $\begin{array}{l}\text { Barriers to Accessibility } \\
\text { and Use of Services }\end{array}$ \\
\hline $\begin{array}{l}\text { McDonnell, E., \& } \\
\quad \text { Ryan, A. A. } \\
2014 \\
\text { Ireland }\end{array}$ & $\begin{array}{l}\text { To explore the experiences of sons car- } \\
\text { ing for a parent with dementia }\end{array}$ & $\begin{array}{l}\text { Methodology: Qualitative } \\
\text { Sample population: } 13 \text { rural sons caring for a } \\
\text { parent with dementia } \\
\text { Rurality: Rural and remote } \\
\text { Sex of CG: } 100 \% \text { male } \\
\text { Sex of PWD: } 92.3 \% \text { female }\end{array}$ & $\begin{array}{l}\text { - All CGs used some form of support service. } \\
\text { - Some sons had to pay privately for extra help. } \\
\text { - Limited services included out of hours care, } \\
\text { respite services tailored to the needs of PWD, } \\
\text { and weekend care. } \\
\text { - Sons reported a lack of consistent information } \\
\text { from service providers. } \\
\text { - Services were often not tailored to meet the } \\
\text { needs of individuals, and were not flexible } \\
\text { enough. }\end{array}$ & None reported \\
\hline $\begin{array}{l}\text { Morgan, D. G., } \\
\text { Kosteniuk, J., } \\
\text { O'Connell, M. E., Dal } \\
\text { Bello-Haas, V., } \\
\text { Stewart, N. J., \& } \\
\text { Karunanayake, C. } \\
2016 \\
\text { Canada }\end{array}$ & $\begin{array}{l}\text { To explore the frequency and perceived } \\
\text { competence of rural home care staff } \\
\text { performing dementia-related activ- } \\
\text { ities, and identify priorities for con- } \\
\text { tinuing education }\end{array}$ & $\begin{array}{l}\text { Methodology: Quantitative } \\
\text { Sample population: } 41 \text { nursing aides and } 41 \\
\text { nurses/case managers } \\
\text { Rurality: Rural and remote } \\
\text { Sex of HSPs: } 93.9 \% \text { female }\end{array}$ & $\begin{array}{l}\text { - } 65 \% \text { of home care aides and only } 18.4 \% \text { of } \\
\text { nurses/managers reported adequate dementia } \\
\text { support services in their community. } \\
\text { - Home care staff engaged in many support } \\
\text { activities including safety issues, providing strat- } \\
\text { egies for managing personal care, and assess- } \\
\text { ing risk of falls. } \\
\text { - Less than half of participants provided support } \\
\text { with legal issues, anticipated changes, effective } \\
\text { communication with the PWD, and managing } \\
\text { behavioral symptoms; confidence doing these } \\
\text { activities was low. }\end{array}$ & None reported \\
\hline $\begin{array}{l}\text { Morgan, D. G., } \\
\text { Semchuk, K. M., } \\
\text { Stewart, N. J., \& } \\
\text { D'Arcy, C. } \\
2002 \\
\text { Canada }\end{array}$ & $\begin{array}{l}\text { To explore the barriers to rural family } \\
\text { caregivers' use of support services }\end{array}$ & $\begin{array}{l}\text { Methodology: Qualitative } \\
\text { Sample population: } 11 \text { directors of care and } 1 \\
\text { district director, } 21 \text { nursing home staff, } 13 \text { home } \\
\text { care providers and staff, } 3 \text { health district board } \\
\text { members, } 7 \text { physicians, and } 13 \text { family CG } \\
\text { Rurality: Rural and remote } \\
\text { Sex of CG: } 92 \% \text { female } \\
\text { Caregiving relationships: } \\
\text { Spouse/ partner }=23.1 \% \\
\text { Daughter }=46.2 \% \\
\text { Daughter-in-law }=23.1 \% \\
\text { Niece }=7.7 \%\end{array}$ & $\begin{array}{l}\text { - Home care staff reported that not enough } \\
\text { support was provided for CG. } \\
\text { - Staff tried to monitor CG's stress and encourage } \\
\text { them to use services such as respite. } \\
\text { - CGs were often reluctant to accept help until } \\
\text { there was a crisis. } \\
\text { - Participants reported limits on the amount and } \\
\text { types of services that were available (e.g., no } \\
24 \text {-hour home care). }\end{array}$ & $\begin{array}{l}\text { - Stigma } \\
\text { - Protecting the PWD } \\
\text { - Desire for privacy } \\
\text { - Denial } \\
\text { - Getting the PWD ready } \\
\text { - Cost of services } \\
\text { - CG beliefs and attitudes } \\
\text { about independence, help, } \\
\text { and caring/guilt } \\
\text { - Lack of knowledge about } \\
\text { services } \\
\text { - Geographical distances } \\
\text { - Respite }\end{array}$ \\
\hline $\begin{array}{l}\text { Morgan, D. G. et al. } \\
2015 \\
\text { Canada }\end{array}$ & $\begin{array}{l}\text { To explore the availability of rural } \\
\text { dementia-related services in Sas- } \\
\text { katchewan, and their orientation } \\
\text { towards aspects of primary health } \\
\text { care }\end{array}$ & $\begin{array}{l}\text { Methodology: Mixed methods } \\
\text { Sample population: } 71 \text { rural home care asses- } \\
\text { sors and coordinators from across the province } \\
\text { Rurality: Rural and remote }\end{array}$ & $\begin{array}{l}\text { - Participants reported limited service options. } \\
\text { - Supports such as counseling and CG support } \\
\text { groups were unavailable or limited. } \\
\text { - Many basic home care services were available, } \\
\text { but respite services (especially weekend and } \\
\text { night respite), and transportation to services } \\
\text { were unavailable or limited. }\end{array}$ & $\begin{array}{l}\text { - Transportation } \\
\text { - Geographical }\end{array}$ \\
\hline
\end{tabular}




\section{Author/s, Year,}

Country

Study Purpose
Findings Related to Support and Education Service Needs, Accessibility, and Use

Methodology and Characteristics of Sample

- Ratings of dementia-related services indicated the following needs: available subsidized/free transportation, equally accessible services regardless of location, appropriate CG support, adequate information for $C G$, and adequate public education to reduce stigma.

\begin{tabular}{lc}
\hline Nordberg, G., von & To describe the amount of formal and \\
Strauss, E., Kåreholt, l., & informal care for rural people with \\
Johansson, L., \& & dementia and those without dementia \\
Wimo, A. & \\
\hline
\end{tabular}

Methodology: Quantitative

Sample population: All people ages $75+$ living

- $50 \%$ of those impaired used formal care: $53 \%$ questionable dementia, $40 \%$ mild impairment, $63 \%$ moderate impairment, and $57 \%$ severe impairment. Informal care predominated.

impairment $[\mathrm{Cl}]$ or dementia

Sex of PWD: $57.4 \%$ female

- PWD living farther away from services did not use fewer formal services than those living close.
Rurality: Rural and remote

Barriers to Accessibility and Use of Services ${ }^{a}$

- For those with mild to severe impairment, men used more formal and informal care.

\begin{tabular}{|c|c|}
\hline $\begin{array}{l}\text { Orpin, P., Stirling, C., } \\
\text { Hetherington, S., \& } \\
\text { Robinson, A. } \\
2014 \\
\text { Australia }\end{array}$ & $\begin{array}{l}\text { To explore the support-seeking expe } \\
\text { ences of caregivers to people with } \\
\text { dementia }\end{array}$ \\
\hline $\begin{array}{l}\text { O'Reilly, M. T., \& } \\
\text { Strong, J. } \\
1997\end{array}$ & $\begin{array}{l}\text { To explore issues important to rural } \\
\text { family caregivers to people with } \\
\text { dementia }\end{array}$ \\
\hline
\end{tabular}

Methodology: Qualitative

Mample popution: 18 rural Rurality: Rural and remote

Sex of CG: $55.6 \%$ male

Caregiving relationships:

Spouse $/$ partner $=55.6 \%$

Child $=44.4 \%$

Sex of PWD: $55.6 \%$ female

- CGs were generally satisfied with the availability, range, and quality of formal support they received; appropriateness was an issue for a small number of CGs.

- Service fragmentation/confusion was an issue.

- Most CGs used short term, in-home respite.

- Almost all CGs had a professional who was trusted and a connection point into services.

\section{Methodology: Qualitative}

Sample population: 7 primary CGs to PWD

Rurality: Rural and remote

Sex of CG: $85.7 \%$

- Available respite included centre-based

Caregiving relationships:

Spouse/ partner $=57.1 \%$

Daughter $=28.6 \%$

Daughter-in-law $=14.3 \%$ dementia-specific (1 day/week), general day, in-home, and residential. CGs needed greater availability of respite, and emergency respite.

- CGs used Meals on Wheels, domiciliary nursing, and counselling.

- CGs perceived their community as well-serviced compared to other rural communities but desired more availability of services.

- CGs needed information on dementia/services.

\begin{tabular}{|c|c|}
\hline $\begin{array}{l}\text { Plunkett, R., \& Chen, P. } \\
2016 \\
\text { Canada }\end{array}$ & $\begin{array}{l}\text { To explore how the church supports } \\
\text { people with dementia in the commu- } \\
\text { nity }\end{array}$ \\
\hline
\end{tabular}

Methodology: Mixed methods

Sample population: Leaders in 25 urban and 26 rural churches

Rurality: Rural and urban groups
- Urban and rural respondents both (64\%) reported their community likely had resources to support PWD and CG, but were unsure of specific dementia-related resources.

- Urban and rural respondents both indicated that greater home care, respite care, and crisis/ emergency support were needed.

- Churches provided individual support to PWD.

- Need exists to enhance social connections for PWD.
- None reported - CG beliefs around
and caring/guilt

- Concerns over provider competence/approach

- Perceptions of out-of-

home respite as disruptive for the PWD

- Suitability of services

- Distance and transportation

- CG reluctance to accept

help and services

- Affordability

\section{- Distance and transporta-} tion 


\begin{tabular}{|c|c|c|c|c|}
\hline $\begin{array}{l}\text { Author/s, Year, } \\
\text { Country }\end{array}$ & Study Purpose & Methodology and Characteristics of Sample & $\begin{array}{l}\text { Findings Related to Support and Education } \\
\text { Service Needs, Accessibility, and Use }\end{array}$ & $\begin{array}{l}\text { Barriers to Accessibility } \\
\text { and Use of Services }\end{array}$ \\
\hline $\begin{array}{l}\text { Putnam, M., Pickard, } \\
\text { J. G., Rodriguez, C., \& } \\
\text { Shear, E. } \\
2010 \\
\text { United States }\end{array}$ & $\begin{array}{l}\text { To explore the importance of support } \\
\text { services for caregivers to persons with } \\
\text { dementia, and perceptions of } \\
\text { consumer-directed care }\end{array}$ & $\begin{array}{l}\text { Methodology: Qualitative } \\
\text { Sample population: } 24 \text { family CGs and one } \\
\text { PWD } \\
\text { Rurality: Rural and urban groups } \\
\text { Sex of CG and PWD: } 92 \% \text { female } \\
\text { Caregiving relationships: } \\
\text { Spouse/partner }=37.5 \% \\
\text { Child }=29.2 \% \\
\text { Other family member }=29.2 \% \\
\text { Friend }=4.2 \%\end{array}$ & $\begin{array}{l}\text { - CGs reported a lack of available and afford- } \\
\text { able services, especially those in rural areas. } \\
\text { - Primary areas of need, in general, included } \\
\text { dementia-specific CG training and education, } \\
\text { respite, and high quality professional services. }\end{array}$ & $\begin{array}{l}\text { - Perceived lack of accept- } \\
\text { ability/suitability } \\
\text { - Affordability of services } \\
\text { and financial barriers }\end{array}$ \\
\hline $\begin{array}{l}\text { Sanders, S., \& } \\
\quad \text { McFarland, P. } \\
2002 \\
\text { United States }\end{array}$ & $\begin{array}{l}\text { To explore the experiences of sons car- } \\
\text { ing for parents with } A D\end{array}$ & $\begin{array}{l}\text { Methodology: Qualitative } \\
\text { Sample population: } 18 \text { son primary caregivers } \\
\text { to parents with AD } \\
\text { Rurality: Primarily rural } \\
\text { Sex of CG: } 100 \% \text { male } \\
\text { Sex of PWD: } 77.8 \% \text { female }\end{array}$ & $\begin{array}{l}\text { - Sons reported support services as crucial; ser- } \\
\text { vices most utilized included day care, home } \\
\text { aides, respite, office of aging, support groups, } \\
\text { Alzheimer's association, and long-term care. } \\
\text { - Many sons felt services met their needs, but } \\
\text { others did not and reported groups were mainly } \\
\text { female CGs, and not targeted enough towards } \\
\text { education and skill-building. } \\
\text { - Sons needed information on services earlier. }\end{array}$ & None reported \\
\hline $\begin{array}{l}\text { Smith, K. et al. } \\
2011 \\
\text { Australia }\end{array}$ & $\begin{array}{l}\text { To describe the unmet needs of remote } \\
\text { Aboriginal Australians, and explore } \\
\text { how care can be facilitated }\end{array}$ & $\begin{array}{l}\text { Methodology: Qualitative } \\
\text { Sample population: } 42 \text { service providers (stage } \\
\text { 1), } 32 \text { Aboriginal CGs, community care work- } \\
\text { ers, and service providers (stage 2); community } \\
\text { representatives, care staff, and aged care ser- } \\
\text { vice providers (stage 3) } \\
\text { Rurality: Rural and remote }\end{array}$ & $\begin{array}{l}\text { - Participants reported a lack of local community } \\
\text { care (except meal services), CG support services, } \\
\text { respite, and activities, } \\
\text { - CGs emphasized their need for more informa- } \\
\text { tion and support. } \\
\text { - Participants identified the need for dementia } \\
\text { education and training, education on available } \\
\text { support services, and culturally safe activities } \\
\text { and services. }\end{array}$ & $\begin{array}{l}\text { - Distance and } \\
\text { - transportation } \\
\text { - Poor communication } \\
\text { between families and staff } \\
\text { - Financial }\end{array}$ \\
\hline $\begin{array}{l}\text { Sun, F., Kosberg, J., } \\
\text { Kaufman, A. V., } \\
\text { Leeper, J. D., \& } \\
\text { Burgin, L. D. } \\
2007 \\
\text { United States }\end{array}$ & $\begin{array}{l}\text { To explore service use and what influ- } \\
\text { ences use among rural families caring } \\
\text { for a person with dementia }\end{array}$ & $\begin{array}{l}\text { Methodology: Quantitative } \\
\text { Sample population: } 141 \text { rural CGs } \\
\text { Rurality: Rural and remote } \\
\text { Sex of CG: } 85 \% \text { female }\end{array}$ & $\begin{array}{l}\text { - Families used an average of } 2 \text { services and over } \\
25 \% \text { used no services. } \\
\text { - The proportions of participants using the fol- } \\
\text { lowing services were visiting nurses }(38 \%) \text {, home } \\
\text { health aides }(33 \%) \text {, home-makers }(25 \%) \text {, case } \\
\text { management }(21 \%) \text {, home-delivered meals } \\
(21 \%) \text {, and counseling }(18 \%) \text {. } \\
\text { - Minimally used services included day care }(7 \%) \text {, } \\
\text { respite }(6 \%) \text {, support groups }(5 \%) \text {, telephone } \\
\text { help }(5 \%) \text {, transportation }(6 \%) \text {, home repairs } \\
(4 \%) \text {, and recreation }(3 \%) \text {. } \\
\text { - Users with a case manager had a higher pro- } \\
\text { portion of service use overall. }\end{array}$ & None reported \\
\hline
\end{tabular}




\begin{tabular}{|c|c|c|c|c|}
\hline $\begin{array}{l}\text { Author/s, Year, } \\
\text { Country }\end{array}$ & Study Purpose & Methodology and Characteristics of Sample & $\begin{array}{l}\text { Findings Related to Support and Education } \\
\text { Service Needs, Accessibility, and Use }\end{array}$ & $\begin{array}{l}\text { Barriers to Accessibility } \\
\text { and Use of Services }\end{array}$ \\
\hline $\begin{array}{l}\text { Teel, C. S. } \\
2004 \\
\text { United States }\end{array}$ & $\begin{array}{l}\text { To explore the experiences of primary } \\
\text { care providers in diagnosis and } \\
\text { treating rural dementia patients }\end{array}$ & $\begin{array}{l}\text { Methodology: Qualitative } \\
\text { Sample population: } 19 \text { rural primary care } \\
\text { providers } \\
\text { Rurality: Rural and remote } \\
\text { Sex of HSP: } 79 \% \text { male }\end{array}$ & $\begin{array}{l}\text { - HSP reported limited local support services; } \\
\text { limited services included community-based } \\
\text { nursing, day care, and respite. } \\
\text { - Only half of respondents knew of community } \\
\text { support groups available to families, and sup- } \\
\text { port groups were identified as lacking. } \\
\text { - HSP viewed education and support for CGs as } \\
\text { important, but had few resources to refer to and } \\
\text { lacked written educational materials. }\end{array}$ & None reported \\
\hline $\begin{array}{l}\text { Wenger, G. C., Burholt, } \\
\text { V., \& Scott, A. } \\
1998 \\
\text { United Kingdom }\end{array}$ & $\begin{array}{l}\text { To compare needs and sources of help } \\
\text { with household tasks between rural } \\
\text { and urban older adults with and } \\
\text { without dementia }\end{array}$ & $\begin{array}{l}\text { Methodology: Quantitative } \\
\text { Sample population: People } 75+\text { with (91) and } \\
\text { without (463) dementia } \\
\text { Rurality: Rural and urban groups } \\
\text { Sex of PWD: } \\
\text { Rural }=75 \% \text { female } \\
\text { Urban }=51 \% \text { female } \\
\text { Sex of PND: } \\
\text { Rural }=62 \% \text { female } \\
\text { Urban }=53 \% \text { male }\end{array}$ & $\begin{array}{l}\text { - PWD were less likely than PND to be able to } \\
\text { manage personal care and ADL without help } \\
\text { - Around } 75 \% \text { of help for PWD and PND was } \\
\text { informal; formal help was most common for } \\
\text { cleaning. PWD were less likely than PND to use } \\
\text { formal services, and had a lot of informal help. }\end{array}$ & None reported \\
\hline $\begin{array}{l}\text { Wenger, G. C., Scott, A., } \\
\quad \text { \& Seddon, D. } \\
2002 \\
\text { United Kingdom }\end{array}$ & $\begin{array}{l}\text { To explore caregivers' experiences and } \\
\text { support in caring for older people } \\
\text { with dementia }\end{array}$ & $\begin{array}{l}\text { Methodology: Qualitative } \\
\text { Sample population: } 40 \text { rural CG } \\
\text { Rurality: Rural and remote } \\
\text { Sex of CG: } 77 \% \text { female } \\
\text { Caregiving relationships: } \\
\text { Spouse/partner }=31 \% \\
\text { Child }=45 \% \\
\text { Other relatives }=15 \% \\
\text { Non-relatives }=10 \%\end{array}$ & $\begin{array}{l}\text { - Informal support predominated. } \\
\text { - In the last } 12 \text { months } 23 \% \text { of CGs used no formal } \\
\text { services, with the following used: aids to daily } \\
\text { living }(42.5 \%) \text {, adaptations }(32.5 \%) \text {, disabled } \\
\text { driver badge }(27.5 \%) \text {, respite }(20 \%) \text {, day care } \\
(22.5 \%) \text {, and home help/care }(25 \%) \text {. A low } \\
\text { number of CG also accessed emergency relief } \\
\text { (2), phone support (2), meals on wheels (3), and } \\
\text { "other" services (5). } \\
\text { - Day care, respite care, and help with incontin- } \\
\text { ence were most highly valued. } \\
\text { - A small minority of CGs reported unmet needs. } \\
\text { - Home sitters and help with bathing were most } \\
\text { frequently reported as inaccessible. } \\
\text { - Advice was most frequently asked of general } \\
\text { practitioners. }\end{array}$ & $\begin{array}{l}\text { - Perceived service inad- } \\
\text { equacy } \\
\text { - CG reluctance to ask for } \\
\text { services } \\
\text { - Process of trying to access } \\
\text { services not offered or } \\
\text { waiting list } \\
\text { - Resistance from PWD }\end{array}$ \\
\hline
\end{tabular}

$A D=$ Alzheimer's disease, $A D L=$ activities of daily living, $C l=$ cognitive impairment, $C G=$ caregiver, $\mathrm{FTD}=$ frontotemporal dementia, $\mathrm{HSP}=$ health/service providers, $\mathrm{LBD}=$ dementia with Lewy bodies, $\mathrm{MCl}=$ mild cognitive impairment, $\mathrm{PND}=$ persons without dementia, $\mathrm{PWD}=$ person $/ \mathrm{s}$ with dementia, RN = registered nurse, VaD = vascular dementia

a Barriers are those reported by participants.

$b$ This article is represented in both Tables 3 and 4 , since its main foci pertained to the assessment of educational needs and intervention evaluation. 


\begin{tabular}{|c|c|c|c|c|}
\hline $\begin{array}{l}\text { Author/s, Year, } \\
\text { Country }\end{array}$ & Intervention/Program & Methodology and Characteristics of Sample & Main Outcomes & Solutions to Barriers \\
\hline $\begin{array}{l}\text { Arai, Y., Arai, A., } \\
\text { Mizuno, Y., } \\
\text { Kamimura, N., } \\
\quad \& \text { lkeda, M. } \\
2017 \\
\text { Japan }\end{array}$ & $\begin{array}{l}\text { An online, downloadable manual on driving and } \\
\text { dementia for family caregivers }\end{array}$ & $\begin{array}{l}\text { Methodology: Quantitative } \\
\text { Sample population: } 1,067 \text { ( } 470 \text { rural) heads of } \\
\text { municipal government, department of welfare } \\
\text { for older citizens } \\
\text { Rurality: Rural and urban groups }\end{array}$ & $\begin{array}{l}\text { - The manual was widely accessed ( } 33,494 \text { times } \\
\text { during the study period). } \\
\text { - } 94 \% \text { of respondents reported they were able to } \\
\text { obtain needed information } \\
\text { - } 23 \% \text { used the manual with families. } \\
\text { - More rural individuals }(29 \%) \text { compared to } \\
\text { urban individuals (20\%) used the manual. }\end{array}$ & $\begin{array}{l}\text { - Technological (Internet) } \\
\text { information dissemin- } \\
\text { ation } \\
\text { - Dissemination through } \\
\text { professionals allows } \\
\text { access to CGs who do } \\
\text { not have Internet. }\end{array}$ \\
\hline $\begin{array}{l}\text { Bateman, C., } \\
\text { Anderson, K., } \\
\text { Bird, M., \& } \\
\text { Hungerford, C. } \\
2016 \\
\text { Australia }\end{array}$ & $\begin{array}{l}\text { Pilot volunteer program to provide person- } \\
\text { centred support (including companionship, } \\
\text { assistance, communication, and activities) for } \\
\text { PWD with dementia and/or delirium in a rural } \\
\text { hospital }\end{array}$ & $\begin{array}{l}\text { Methodology: Mixed methods } \\
\text { Sample population: } 18 \text { hospital staff and } 18 \\
\text { volunteers, caring for } 64 \text { patients } \\
\text { Rurality: Rural and remote } \\
\text { Sex of PWD: } 68 \% \text { female }\end{array}$ & $\begin{array}{l}\text { - No pre-post changes in staff stress, hope, or } \\
\text { person-centred care. } \\
\text { - High rate of completion for volunteers; no } \\
\text { change in dementia and delirium scores but an } \\
\text { increase in hope and understanding of person- } \\
\text { centred care and patient needs. } \\
\text { - Almost all staff reported the program was val- } \\
\text { ved, should stay, and that is improved quality of } \\
\text { care and patient outcomes. } \\
\text { - As project became established length of patient } \\
\text { stay was almost halved, with a significant } \\
\text { increase and psychotropic meds and small } \\
\text { increase in analgesia. }\end{array}$ & $\begin{array}{l}\text { - Program provided } \\
\text { person-centred support. }\end{array}$ \\
\hline $\begin{array}{l}\text { Brijoux, T., Kri- } \\
\text { cheldorff, C., } \\
\text { Hüll, M., \& } \\
\text { Bonfico, S. } \\
2016 \\
\text { Germany }\end{array}$ & $\begin{array}{l}\text { An expanded volunteer care companion pro- } \\
\text { gram for the families of PWD that includes } \\
\text { counseling, support using additional care ser- } \\
\text { vices, and dementia-specific knowledge train- } \\
\text { ing }\end{array}$ & $\begin{array}{l}\text { Methodology: Quantitative } \\
\text { Sample population: } 63 \text { rural caregivers to } \\
\text { PWD } \\
\text { Rurality: Rural and remote } \\
\text { Sex of HSP: } 74 \% \text { female } \\
\text { Caregiving relationships: } \\
\text { Spouse/partner }=58.8 \% \\
\text { Child }=37 \% \\
\text { Sibling }=3.2 \% \\
\text { Grandchild }=1.6 \%\end{array}$ & $\begin{array}{l}\text { - CG mental but not physical health-related QOL } \\
\text { increased for the intervention but not control } \\
\text { group (who received the basic intervention). } \\
\text { - Few differences in CG burden existed between } \\
\text { the two groups; large decrease in family role } \\
\text { conflict observed. } \\
\text { - Knowledge and use of other supportive services } \\
\text { increased across both groups. }\end{array}$ & $\begin{array}{l}\text { - Service use increased } \\
\text { CG knowledge and use } \\
\text { of other services } \\
\text { - Education and support } \\
\text { offered for using other } \\
\text { services }\end{array}$ \\
\hline $\begin{array}{l}\text { Brotons, M., \& } \\
\quad \text { Marti, P. } \\
2003 \\
\text { Spain }\end{array}$ & $\begin{array}{l}\text { Pilot music therapy program focused on music- } \\
\text { related activities and communication, for rural } \\
\text { PWD and CGs }\end{array}$ & $\begin{array}{l}\text { Methodology: Mixed methods } \\
\text { Sample population: } 14 \text { PWD and their spousal } \\
\text { CG }(n=28) \\
\text { Rurality: Rural and remote } \\
\text { Sex of CG: } 64.3 \% \text { female } \\
\text { Caregiving relationships: } \\
\text { Spouse/partner }=100 \% \\
\text { Sex of PWD: } 35.7 \% \text { female } \\
\text { Dementia diagnoses: } A D=100 \%\end{array}$ & $\begin{array}{l}\text { - Improvements in attention span, expressive } \\
\text { language, and short-and long-term memory } \\
\text { were observed by staff. } \\
\text { - CGs reported improvements in the social } \\
\text { behaviours }(50 \%) \text {, emotional state }(66.7 \%) \text {, and } \\
\text { physical/motor abilities }(33 \%) \text { of their spouse. } \\
\text { - Psychopathology, behavior problems, and agi- } \\
\text { tation were lower post-intervention. } \\
\text { - CGs reported the intervention helped them } \\
\text { relax and offered a space for expression of } \\
\text { feelings; lower anxiety post-intervention but no } \\
\text { change in depression or burden. }\end{array}$ & $\begin{array}{l}\text { - The authors stated that } \\
\text { CGs showed increas- } \\
\text { ingly open attitudes } \\
\text { towards support ser- } \\
\text { vices. }\end{array}$ \\
\hline
\end{tabular}


Table 5: Continued

\begin{tabular}{|c|c|c|c|c|}
\hline $\begin{array}{l}\text { Author/s, Year, } \\
\text { Country }\end{array}$ & Intervention/Program & Methodology and Characteristics of Sample & Main Outcomes & Solutions to Barriers \\
\hline $\begin{array}{l}\text { Clancy, A. } \\
2015 \\
\text { Australia }\end{array}$ & $\begin{array}{l}\text { Dementia Outreach Service (DOS) for PWD and } \\
\text { CG, including home visits, case management, } \\
\text { phone support, assistance with behaviours, } \\
\text { advocacy, referral, and liaison with geriatri- } \\
\text { cians; group education and support programs } \\
\text { are also offered }\end{array}$ & $\begin{array}{l}\text { Methodology: Qualitative } \\
\text { Sample population: } 6 \text { Outreach Service staff, } 7 \\
\text { service providers, and } 8 \text { people with expertise } \\
\text { in dementia and/or a health discipline } \\
\text { Rurality: Rural and remote }\end{array}$ & $\begin{array}{l}\text { - Large distances, poor transportation options, } \\
\text { and age were identified as barriers to accessing } \\
\text { services. } \\
\text { - Participants identified } 7 \text { core activities key to the } \\
\text { Outreach Service: (1) sector leadership; (2) } \\
\text { flexibility and responsiveness; (3) linking (clients } \\
\text { and carers; clients with specialist services, com- } \\
\text { munity partners); (4) program innovation; (5) } \\
\text { building cohesion within the sector; (6) clinical } \\
\text { consultation for people working within the sec- } \\
\text { tor; and (7) case management. }\end{array}$ & $\begin{array}{l}\text { - DOS outreach into } \\
\text { homes } \\
\text { - The provision of local } \\
\text { programs } \\
\text { - Collaboration between } \\
\text { multiple community } \\
\text { partners }\end{array}$ \\
\hline $\begin{array}{l}\text { Coogle, C. L. } \\
2002 \\
\text { United States }\end{array}$ & $\begin{array}{l}\text { Educational intervention for CG to PWD, con- } \\
\text { sisting of informational workshops addressing } \\
\text { topics related to } A D \text {, patient behaviours and } \\
\text { competencies, formal and informal care, and } \\
\text { interventions/ CG resources }\end{array}$ & $\begin{array}{l}\text { Methodology: Quantitative } \\
\text { Sample population (intervention portion of } \\
\text { the study): } 106 \text { family CGs (predominantly } \\
\text { African American; } 70.3 \% \text { rural) } \\
\text { Rurality: Rural and urban groups } \\
\text { Sex of CG: } 84.6 \% \text { female }\end{array}$ & $\begin{array}{l}\text { - Authors previously reported the relevance of } \\
\text { the intervention, and gains in knowledge about } \\
\text { AD, caregiving, and community resources; CG } \\
\text { were also more likely to access supports. } \\
\text { - African American CGs were more aware of } \\
\text { community supports, learned more about } \\
\text { workshop content, and found the information } \\
\text { more useful than Caucasian CGs (no differences } \\
\text { in knowledge scores). } \\
\text { - Rural CGs did not evaluate the intervention } \\
\text { differently than urban CGs, but scored signifi- } \\
\text { cantly lower in knowledge overall and man- } \\
\text { aging the daily routine. }\end{array}$ & $\begin{array}{l}\text { - Transportation expenses } \\
\text { were reimbursed. } \\
\text { - Multiple respite care } \\
\text { options were provided } \\
\text { to attendees. } \\
\text { - Education on other ser- } \\
\text { vices/resources pro- } \\
\text { vided. }\end{array}$ \\
\hline $\begin{array}{l}\text { Dal Bello-Haas, } \\
\text { V. P. M., } \\
\text { O'Connell, M., } \\
\text { Morgan, D. G., } \\
\text { \& Crossley, M. } \\
2014 \text { b } \\
\text { Canada }\end{array}$ & $\begin{array}{l}\text { Telehealth-delivered exercise pilot intervention } \\
\text { for rural PWD and CG, focused on aerobic } \\
\text { exercise using an upper extremity cycle erg- } \\
\text { ometer }\end{array}$ & $\begin{array}{l}\text { Methodology: Mixed methods } \\
\text { Sample population: } 42 \text { PWD and } 51 \text { CGs } \\
\text { ( } n=77) \text { participated in a survey; } 2 \text { PWD/CG } \\
\text { dyads participated in the pilot intervention } \\
\text { Rurality: Rural and remote } \\
\text { Dementia diagnoses: } \\
\text { AD }=1, \text { FTD }=1\end{array}$ & $\begin{array}{l}\text { - Only openness to group-based exercise (not } \\
\text { attitudes towards exercise, distance to a tele- } \\
\text { health site, or computer ownership) was a pre- } \\
\text { dictor of PWD and CG willingness to participate } \\
\text { in the intervention. } \\
\text { - Participants were engaged and rated all aspects } \\
\text { of the intervention highly: ease getting to the } \\
\text { telehealth site, quality of technology, privacy, } \\
\text { engagement with the group and facilitator, } \\
\text { ability to exercise, social connection, and overall } \\
\text { experience. }\end{array}$ & $\begin{array}{l}\text { - Technological (tele- } \\
\text { health) service provision }\end{array}$ \\
\hline
\end{tabular}




\section{Author/s, Year,}

\begin{tabular}{ll}
$\begin{array}{l}\text { Author/s, Year, } \\
\text { Country }\end{array}$ & Intervention/Program \\
\hline Downes, S. & $\begin{array}{c}\text { Rural respite centre based on the Eden Principles } \\
\text { that offers programming including day pro- } \\
\text { grams, short-term overnight respite, education, } \\
\text { support groups, advocacy, and community }\end{array}$ \\
Australia & $\begin{array}{l}\text { support vists } \\
\end{array}$
\end{tabular}

Methodology: Mixed methods

Sample population: 34 CGs to PWD using the services; dementia care mapping (DCM) was also conducted with PWD support visits
Rurality: Rural and remote Sex of CG: $71 \%$ female
- DCM showed PWD spent a significant amount of time socializing and in activities with high potential for well-being.

- CGs reported higher-than average well-being and health, and lower burden.

- CGs reported the centre made their lives easier $(100 \%)$, and decreased stress (80\%).

- $90 \%$ of CGs disagreed their relative was lonely during service use; $82.3 \%$ disagreed they were bored; $75 \%$ agreed their relative participated in decision making; and 100\% reported positive communication with staff.

\begin{tabular}{|c|c|}
\hline $\begin{array}{l}\text { Ervin, K., \& } \\
\quad \text { Moore, S. } \\
2014 \\
\text { Australia }\end{array}$ & $\begin{array}{l}\text { Volunteer program to provide person-centred } \\
\text { cognitive and emotional support and com- } \\
\text { panionship to PWD in a rural hospital }\end{array}$ \\
\hline
\end{tabular}

\section{Methodology: Qualitative}

Sample population: 15 nurses working in the

hospital during the intervention period

Rurality: Rural and remote

Sex of HSP: $100 \%$ female

- Nurses reported the volunteer support helped with their own time management, decreased patient falls and other injuries, and benefited patients with support, comfort, and increased opportunity for stimulation and recreational activities.

- Participants desired the extension of the program to evenings and weekends.

Gigliotti, C. M., Horticulture therapy (HT) activities (planting, Jarrott, S. E., \& cooking, and crafts) as part of a universityYorgason, J. based, adult day services program for PWD 2004
Methodology: Quantitative

Sample population: 14 rural PWD attending the program

Rurality: Rural and remote
- Time PWD spent engaged in HT activities was high, and time doing nothing was lower compared to traditional activities.

- Positive affect was higher than with traditiona activities although there was a lot of variation between participants.

- CGs in the intervention (versus standard support and education control) group showed significant pre-post improvement in perceived caregiving self-efficacy, and resolving caregiving problems.

- No significant pre-post-test differences in CG burden or depressive affect were observed though trends were positive.

- CG reported high satisfaction with the program and would recommend it to others.

Sex of PWD: $78.6 \%$ female

Dementia diagnoses:

$\mathrm{AD}=8, \mathrm{VaD}=6$

$\begin{array}{cc}\text { Hicken, B. L., } & \text { Electronic (Internet/touch screen telehealth } \\ \text { Daniel, C., } & \text { device) CG support and education interven- } \\ \text { Luptak, M., } & \text { tion, focused on dementia education, skill } \\ \text { Grant, M., } & \text { training to improve interactions with the PWD, }\end{array}$

Methodology: Quantitative

Sample population: 231 CGs to veterans with dementia (53\% lived in rural or highly rural areas)
- Few changes were observed across Internet telehealth, and phone (control) groups. No significant changes on CG burden, conflict, desire to institutionalize, or depressive symptoms; some
- The Centre shaped services and activities around the needs, interests, and desires of users. - Public/community education was available.

- Program provided person-centred support.

- Provision of meaningful activities and a way to appeal to a broader spectrum of interests

- Technological (phone) service/information provision

- Technological (telehealth, phone, and Internet) service/information provision 


\begin{tabular}{|c|c|c|c|c|}
\hline $\begin{array}{l}\text { Author/s, Year, } \\
\text { Country }\end{array}$ & Intervention/Program & Methodology and Characteristics of Sample & Main Outcomes & Solutions to Barriers \\
\hline $\begin{array}{l}\text { Kilian, S., \& } \\
\text { Rupper, R. W. } \\
2017 \\
\text { United States }\end{array}$ & $\begin{array}{l}\text { self-care strategies, and care manager support } \\
\text { to link CG to services }\end{array}$ & $\begin{array}{l}\text { Rurality: Rural and urban groups } \\
\text { Sex of CG: } 90 \% \text { female } \\
\text { Caregiving relationships: } \\
\text { Spouse }=74 \% \\
\text { Other }=26 \%\end{array}$ & $\begin{array}{l}\text { decreases in grief and perceived hardship for } \\
\text { Internet/telehealth users. } \\
\text { - Both urban and rural Internet/telehealth groups } \\
\text { reported decreased worry and felt isolation. }\end{array}$ & $\begin{array}{l}\text { - Alternative modalities to } \\
\text { avoid relying on partici- } \\
\text { pant access to and } \\
\text { comfort with Internet } \\
\text { - Care manager to link } \\
\text { CG to other supports }\end{array}$ \\
\hline $\begin{array}{l}\text { Jo, H. K., \& Song, } \\
\text { M. R. } \\
2016 \\
\text { Korea }\end{array}$ & $\begin{array}{l}\text { Integrated cognitive behavioural program for } \\
\text { PWD, including hands \& feet exercise, CBT } \\
\text { strategy/ activity performance, and concept } \\
\text { memory training }\end{array}$ & $\begin{array}{l}\text { Methodology: Quantitative } \\
\text { Sample population: } 46 \text { rural CG/PWD dyads } \\
\quad(n=82) \\
\text { Rurality: Rural and remote }\end{array}$ & $\begin{array}{l}\text { - No significant pre-post differences found in } \\
\text { responsive behaviours, but IADL improved. } \\
\text { - CG burden decreased in the intervention group, } \\
\text { but not quality of life. }\end{array}$ & \\
\hline $\begin{array}{l}\text { La Rue, A. et al. } \\
2013 \\
\text { United States }\end{array}$ & $\begin{array}{l}\text { Longitudinal intervention adapted for rural PWD, } \\
\text { focused on physical exercise (aerobic, strength, } \\
\text { and flexibility and balance), language and } \\
\text { memory (verbal exercises), and social and vol- } \\
\text { unteer outings }\end{array}$ & $\begin{array}{l}\text { Methodology: Quantitative } \\
\text { Sample population: } 8 \text { intervention participants } \\
\text { with dementia (excluding FTD) who had com- } \\
\text { pleted 1-year follow-up data } \\
\text { Rurality: Primarily rural } \\
\text { Sex of PWD: } 50 \% \text { female }\end{array}$ & $\begin{array}{l}\text { - No differences found between baseline and } 1 \\
\text { year on global cognitive function, mood, and } \\
\text { physical fitness. } \\
\text { - MMSE scores improved slightly from baseline to } \\
\text { follow-up. } \\
\text { - There was a trend towards lower quality of life } \\
\text { ratings at } 1 \text {-year follow-up. } \\
\text { - A trend towards improvement doing arm curls } \\
\text { was observed at 1-year follow-up. }\end{array}$ & $\begin{array}{l}\text { - Adapted locations to fit } \\
\text { rural locations (sessions } \\
\text { at home or convenient } \\
\text { community locations) } \\
\text { - Individual rather than } \\
\text { group intervention } \\
\text { - Use of volunteers to } \\
\text { increase sustainability }\end{array}$ \\
\hline $\begin{array}{l}\text { La Rue, A., Felten, } \\
\text { K., \& Turkstra, L. } \\
2015 \\
\text { United States }\end{array}$ & $\begin{array}{l}\text { Longitudinal intervention adapted for rural PWD, } \\
\text { focused on physical exercise (aerobic, strength, } \\
\text { and flexibility and balance), language and } \\
\text { memory (verbal exercises), and social and vol- } \\
\text { unteer outings }\end{array}$ & $\begin{array}{l}\text { Methodology: Quantitative } \\
\text { Sample population: } 64 \text { PWD (excluding FTD); } \\
29 \text { completed the first follow-up and } 7 \text { com- } \\
\text { pleted the second follow-up } \\
\text { Rurality: Primarily rural } \\
\text { Sex of PWD: } 56.3 \% \text { female } \\
\text { Dementia diagnoses: } A D=65.5 \% \text {, dementia } \\
\text { unspecified/other }=26.6 \%, M C l=6.3 \% \text {, } \\
\text { pending diagnosis }=1.6 \%\end{array}$ & $\begin{array}{l}\text { - At first follow-up, scores remained stable other } \\
\text { than an increase in number of arm curls and } \\
\text { decrease in quality of life; MMSE scores did not } \\
\text { change and were better than expected based } \\
\text { on mean annual decline for PWD. } \\
\text { - All participants showed increased exercise dur- } \\
\text { ation, and at second follow-up there were no } \\
\text { significant differences from baseline in cognition, } \\
\text { physical fitness, well-being, or minutes of exer- } \\
\text { cise endurance at peak month vs. initial month. }\end{array}$ & $\begin{array}{l}\text { - Adapted locations to fit } \\
\text { rural locations (sessions } \\
\text { at home or convenient } \\
\text { community locations) } \\
\text { - Individual rather than } \\
\text { group intervention } \\
\text { - Use of volunteers to } \\
\text { increase sustainability }\end{array}$ \\
\hline $\begin{array}{l}\text { Moore, W. R. } \\
2002 \\
\text { United States }\end{array}$ & $\begin{array}{l}\text { Psychosocial telephone support group for rural } \\
\text { gay and lesbian CG to PWD, focused on social } \\
\text { support, grief, caregiving, relationships with } \\
\text { family and faith communities, legal issues, } \\
\text { coping with challenging behaviours, and inter- } \\
\text { acting with formal care systems }\end{array}$ & $\begin{array}{l}\text { Methodology: Mixed methods } \\
\text { Sample population: } 7 \text { rural lesbian and gay } \\
\text { CGs to their partner with dementia } \\
\text { Rurality: Rural and remote } \\
\text { Sex of CG: } 71.4 \% \text { female } \\
\text { Sex of PWD: } 71.4 \% \text { female } \\
\text { Dementia diagnoses: } A D=4 \text {, multi-stroke } \\
\text { infarction }=2 \text {, multiple diagnoses including } \\
\text { AD }=1\end{array}$ & $\begin{array}{l}\text { - Participants perceived mainstream support } \\
\text { - Troups as unsuitable for them. } \\
\text { lation and increased their support system, } \\
\text { affirmed their determination to provide care, } \\
\text { and strengthened their confidence to keep their } \\
\text { partner at home. } \\
\text { - The support group allowed CGs a safe place to } \\
\text { discuss resources, experiences, and challenges } \\
\text { (including accessing supports). } \\
\text { - Members created rapport and contacted each } \\
\text { other between and after sessions. }\end{array}$ & $\begin{array}{l}\text { - Technological service } \\
\text { provision (telephone) } \\
\text { - Service provision } \\
\text { tailored to the needs of } \\
\text { a subgroup of CG }\end{array}$ \\
\hline
\end{tabular}




\begin{tabular}{|c|c|c|c|c|}
\hline $\begin{array}{l}\text { Author/s, Year, } \\
\text { Country }\end{array}$ & Intervention/Program & Methodology and Characteristics of Sample & Main Outcomes & Solutions to Barriers \\
\hline $\begin{array}{l}\text { Nomura, M. et al. } \\
2009 \\
\text { Japan }\end{array}$ & $\begin{array}{l}\text { Program to empower PWD and CG, including (1) } \\
\text { activity-based programming for PWD focused } \\
\text { on health counseling, cognitive rehabilitation- } \\
\text { based cooking activities, and other activities } \\
\text { designed to improve memory function; and (2) } \\
\text { CG education on dementia and resources and } \\
\text { counseling (problem-focused coping and } \\
\text { strategies) }\end{array}$ & $\begin{array}{l}\text { Methodology: Qualitative } \\
\text { Sample population: } 37 \text { PWD and } 31 \text { CGs using } \\
\text { the program } \\
\text { Rurality: Rural and remote } \\
\text { Sex of CG: } 71 \% \text { female } \\
\text { Sex of PWD: } 70.3 \% \text { female } \\
\text { Caregiving relationships: Spouse }=41.9 \% \\
\text { Child = } 35.5 \% \\
\text { Daughter-in-law }=22.6 \% \\
\text { Dementia diagnoses: } A D=17, \mathrm{VaD}=5 \\
\mathrm{MCl}=15\end{array}$ & $\begin{array}{l}\text { - CGs perceived day care services to be for } \\
\text { people at an advanced stage of dementia and } \\
\text { reported stigma around resource use. } \\
\text { - Afternoon activities did not always engage } \\
\text { PWD and were modified to accommodate cul- } \\
\text { tural and personal backgrounds. } \\
\text { - All PWD regained procedural skills related to } \\
\text { the cooking activities. } \\
\text { - Communication strategies increased positive } \\
\text { interactions with family members. } \\
\text { - PWD bonded and the program started to serve } \\
\text { as a self-help group. } \\
\text { - PWD were proud to display skills to family and } \\
\text { community members. } \\
\text { - Education and counseling improved CG } \\
\text { approaches to responsive behaviours, } \\
\text { increased problem-focused coping skills, and } \\
\text { improved family relationships. }\end{array}$ & $\begin{array}{l}\text { - Technological service } \\
\text { provision (counseling by } \\
\text { telephone) } \\
\text { - Education on resources } \\
\text { and services } \\
\text { - A case study in CG } \\
\text { education illustrated } \\
\text { benefits of resource use } \\
\text { and reduce mispercep- } \\
\text { tions } \\
\text { - Program flexibility to } \\
\text { accommodate the } \\
\text { backgrounds and inter- } \\
\text { ests of PWD }\end{array}$ \\
\hline $\begin{array}{l}\text { O'Connell, M. E., } \\
\text { Crossley, M., } \\
\text { Cammer, A., \& } \\
\text { Morgan, D. } \\
2014 \\
\text { Canada }\end{array}$ & $\begin{array}{l}\text { Telehealth support group for rural CG whose } \\
\text { spouse was diagnosed with atypical young } \\
\text { onset dementias, focused primarily on emotion } \\
\text { processing }\end{array}$ & $\begin{array}{l}\text { Methodology: Qualitative } \\
\text { Sample population: } 10 \text { spousal CGs to persons } \\
\text { with FTD and other young onset dementias } \\
\text { Rurality: Rural and remote } \\
\text { Dementia diagnoses: } 8 \text { variants of FTD } \\
\text { (progressive non-fluent aphasia }=1 \text {, semantic } \\
\text { dementia }=3 \text {, and behavioural variant }=4 \text { ), } \\
\text { dementia secondary to Huntington's disease }=1 \text {, } \\
\text { and vascular strokes }=1\end{array}$ & $\begin{array}{l}\text { - CGs needed emotional processing and support } \\
\text { more than information. } \\
\text { - CGs appreciated having others in the group } \\
\text { with similar circumstances and found the social } \\
\text { contact valuable. More socialization (including } \\
\text { in-person) was desired. } \\
\text { - CGs appreciated learning what worked for } \\
\text { others, and practical information (e.g., navigat- } \\
\text { ing home care). } \\
\text { - Telehealth reduced but did not ameliorate travel } \\
\text { burden; some challenges found (e.g., interpret- } \\
\text { ing non-verbal cues, technical glitches). }\end{array}$ & $\begin{array}{l}\text { - Technological service } \\
\text { provision (telehealth) } \\
\text { - Group tailored to the } \\
\text { needs of a specific } \\
\text { population: CG to per- } \\
\text { sons with atypical, } \\
\text { young-onset dementias }\end{array}$ \\
\hline $\begin{array}{l}\text { Paddick, S. M. } \\
\quad \text { et al. } \\
2017 \\
\text { Tanzania }\end{array}$ & $\begin{array}{l}\text { Cognitive stimulation therapy program for PWD, } \\
\text { including elements of reality orientation, valid- } \\
\text { ation therapy, and reminiscence therapy }\end{array}$ & $\begin{array}{l}\text { Methodology: Quantitative } \\
\text { Sample population: } 34 \text { rural PWD and their } \\
\text { primary CGs } \\
\text { Rurality: Rural and remote } \\
\text { Sex of PWD: } 85.3 \% \text { female } \\
\text { Dementia diagnoses: } A D=47.1 \%, V a D=29.4 \% \text {, } \\
\text { Parkinson's disease dementia }=5.9 \%, \text { probable } \\
\text { LBD }=5.9 \% \text {, mixed/unclear subtypes }=11.7 \%\end{array}$ & $\begin{array}{l}\text { - PWD improved cognitively pre-post interven- } \\
\text { tion, and in physical (but not psychological) } \\
\text { health quality of life. } \\
\text { - CGs reported pre-post improvements in anx- } \\
\text { iety, but not CG burden. } \\
\text { - CG reported pre-post improvements in behav- } \\
\text { ioural and psychological symptoms of the PWD } \\
\text { (depressive symptoms, night time disturbance, } \\
\text { and changes in appetite). } \\
\text { - Health care expenses did not differ pre-post } \\
\text { intervention. } \\
\text { - Travel was a barrier for some participants. }\end{array}$ & $\begin{array}{l}\text { - Therapy was tailored to } \\
\text { cultural and educational } \\
\text { characteristics. } \\
\text { - Setting and resources } \\
\text { were carefully con- } \\
\text { sidered to enhance } \\
\text { accessibility. }\end{array}$ \\
\hline
\end{tabular}




\section{Author/s, Year}

Country Intervention/Program

Paul, L., Johnson, Interactive teleconference for rural CGs in Mon-

A. O., \&

Cranston,

G. M.

2000 tana focused on nutrition for PWD, including broadcast, video copies, handouts, and a

Methodology: Mixed methods

Sample population: 66 informal and formal CGs, at 23 videoconference sites

United States
- $97 \%$ of CGs rated the conference as good or better and 100\% would attend another, $89 \%$ felt it was organized and clear, and $88 \%$ found the content applicable.

- Strengths included the quality of speakers and information provided, time and travel expenses ference and video) pite.
Scharf, L.,

Bell, P. A., \&

Smith, S. A.

2006

United States
Psychoeducational program for CG, consisting of Methodology: Quantitative

12 hours of in-person sessions $(1,2$, or 3$)$; a manual with education and skill information focused on dementia, self-care, enjoyable involvement, thinking and performance: and the family as a resource for caregiving; and CD-ROM with information, a cognitive performance estimation procedure, and interventions for challenging behaviours
Sample population: 101 CGs to persons with

$A D$ or other dementias

Rurality: Rural and remote

Caregiving relationships:

Spouse $=27$

Child/Child in-law $=39$

Sibling $=4$

Friend or neighbor $=4$

Other relative $=1$

Professional or other non-relative $=26$
- 93-100\% of CGs felt the training was relevant and that they learned useful strategies for caregiving, were more knowledgeable, had more skills, were more confident, and would recommend the program to others. material somewhat regularly, $72 \%$ used the manual to help structure meaningful activities for the PWD, and 39\% had used the CD-ROM (32\% to determine the PWD's level of function-

- CGs increased their use of support groups after training but not total services used.

- Sex, number of years as CG, place of residence, relationship to PWD, and \# of training sessions did not affect results.

Smith, S., \& Bell, P. Psychoeducational program for CGs, consisting 2005

United States

More urban (47\%) compared to rural (17\%) CGs were using a support group at baseline; there was an overall increase in support group of: 12 hours of in-person sessions; a manual with education and skill information focused on dementia, self-care, enjoyable involvement, thinking and performance, and the family as a resource for caregiving; and a CD-ROM with information, a cognitive performance estimation procedure, and interventions for challenging behaviours

\section{Methodology: Quantitative}

Sample population: 54 rural and 42 urban

CGs to people with $A D$

Rurality: Rural and urban groups

Sex of CG (rural): $73 \%$ female

CG relationships (rural):

Spouse/ partner $=17$

Child/Child in-law $=26$

Sibling $=3$

Friend or neighbor $=3$

Other relative $=1$ saved, interaction with others at the sites, the interactive (call-in) format, and the information in handouts.

- There were some technological difficulties with the satellite teleconferencing.

- Respondents requested info on activities to increase nutritional quality and intake, local support groups and available resources, behavioural management, and hiring/firing in-home care staff.

- Six months after training 75\% of CGs used the

- Technological (teleconinformation provided. Schedule tried to accommodate CG need for res-

- Language and level of information was tailored to the target audiences. usage at 6-month follow-up.

- $88 \%$ of rural participants used the manual frequently after training; $69 \%$ found it helpful in structuring meaningful activities for the PWD. $38 \%$ had used the CD-ROM and $35 \%$ used it to determine level of functioning. No significant differences found between urban and rural groups in use.

- Rural CG (but not urban CG)'s depression scores declined pre-post follow-up.
- Program adapted to ewer session times, for rural accessibility.

- Materials intended for use at any time to avoid the need for readily available local

\section{resources.}

- Program may have increased participation in support groups.

- Materials intended for use at any time to avoid the need for readily available local resources. 


\begin{tabular}{|c|c|c|c|c|}
\hline $\begin{array}{l}\text { Author/s, Year, } \\
\text { Country }\end{array}$ & Intervention/Program & Methodology and Characteristics of Sample & Main Outcomes & Solutions to Barriers \\
\hline $\begin{array}{l}\text { Taylor, K. A., Lin- } \\
\text { deman, M. A., } \\
\text { Stothers, K., } \\
\text { Piper, K., \& } \\
\text { Kuipers, P. } \\
2012 \\
\text { Australia }\end{array}$ & $\begin{array}{l}\text { DVD intended to raise awareness about demen- } \\
\text { tia, created in English and three local Aborigi- } \\
\text { nal languages (Warlpiri, Kriol, and } \\
\text { Diambarrpuyngu) }\end{array}$ & $\begin{array}{l}\text { Methodology: Qualitative } \\
\text { Sample population: } 26 \text { Indigenous aged care } \\
\text { workers, service users, and community mem- } \\
\text { bers; } 5 \text { health care professionals and service } \\
\text { coordinators } \\
\text { Rurality: Rural and remote }\end{array}$ & $\begin{array}{l}\text { - Resource was effective in raising awareness } \\
\text { about dementia (including risk), which was low } \\
\text { even for family CGs. } \\
\text { - Understanding dementia symptoms decreased } \\
\text { negative feelings of HSP and CG towards PWD, } \\
\text { and interpersonal tension. } \\
\text { - Aboriginal language versions were well- } \\
\text { received; English subtitles would be helpful for } \\
\text { teaching purposes. } \\
\text { - The resource raised anxiety about getting } \\
\text { dementia for some participants. } \\
\text { - Information prompted people to connect to } \\
\text { services and reduced CG isolation. }\end{array}$ & $\begin{array}{l}\text { - Culturally safe educa- } \\
\text { tion, developed with } \\
\text { local Aboriginal people } \\
\text { - Language-matched } \\
\text { resources } \\
\text { - Information increased } \\
\text { connections to other } \\
\text { services }\end{array}$ \\
\hline $\begin{array}{l}\text { Tomkins, S. A., \& } \\
\text { Bell, P. A. } \\
2009 \\
\text { United States }\end{array}$ & $\begin{array}{l}\text { Psychoeducational program for CG, consisting of: } \\
12 \text { hours of in-person sessions; a manual with } \\
\text { education and skill information focused on } \\
\text { dementia, self-care, enjoyable involvement, } \\
\text { thinking and performance, and the family as a } \\
\text { resource for caregiving; and a CD-ROM with } \\
\text { information, a cognitive performance estima- } \\
\text { tion procedure, and interventions for challen- } \\
\text { ging behaviours. Respite grant for up to } \$ 1,000 \\
\text { per family, for use of day care, in-home care, } \\
\text { or other respite }\end{array}$ & $\begin{array}{l}\text { Methodology: Quantitative } \\
\text { Sample population: Rural and urban CGs } \\
\text { participating in the program intervention (127), } \\
\text { receiving a respite grant (197), or both (43) } \\
\text { Rurality: Rural and urban groups } \\
\text { Sex: } 64 \% \text { female } \\
\text { Caregiving relationships: } \\
\text { Spouse/partner }=52 \% \\
\text { Child/child-in-law }=41 \% \\
\text { Sibling }=3 \% \\
\text { Neighbour }=2 \% \\
\text { Other relative }=2 \% \\
\text { Professional/other non-relative }=5 \%\end{array}$ & $\begin{array}{l}\text { - As in previous articles about this program, it was } \\
\text { positively received and used by CG. } \\
\text { - CG receiving the grant used it for in-home } \\
\text { respite }(49 \%) \text {, day program (30\%), and a short } \\
\text { stay in a nursing home (15\%). } \\
\text { - Overall depression scores decreased signifi- } \\
\text { cantly pre- intervention and grant to 6-month } \\
\text { follow-up; women and the grant group had } \\
\text { higher depression scores. } \\
\text { - Overall health increased from baseline to } \\
\text { 6-month follow-up. } \\
\text { - Overall service use increased over time, par- } \\
\text { ticularly for CGs with the grant (with or without } \\
\text { program), and urban CGs more than rural. } \\
\text { - CGs reported as "other" showed a smaller } \\
\text { increase in service use compared to spouses and } \\
\text { children. } \\
\text { - } 26 \% \text { of CGs reported increased support group } \\
\text { use pre-post intervention. }\end{array}$ & $\begin{array}{l}\text { - Respite voucher and } \\
\text { free program to } \\
\text { decrease financial bar- } \\
\text { riers } \\
\text { - Materials intended for } \\
\text { use at any time to avoid } \\
\text { need for readily avail- } \\
\text { able local resources } \\
\text { - Increased awareness } \\
\text { and use of support ser- } \\
\text { vices possible by contact } \\
\text { with other CGs and } \\
\text { program }\end{array}$ \\
\hline
\end{tabular}

a This article is represented in both Tables 3 and 4, since its main foci pertained to the assessment of educational needs and intervention evaluation.

Note. $A D=$ Alzheimer's disease, $A D L=$ activities of daily living, $C G=$ caregiver, $\mathrm{Cl}=$ cognitive impairment, $\mathrm{FTD}=$ frontotemporal dementia, $\mathrm{HSP}=$ health/service providers, $I A D L=$ instrumental activities of daily living, $L B D=$ dementia with Lewy bodies, $M C l=$ mild cognitive impairment, $M M S E=M i n i$ Mental State Examination, $P N D=$ person $/ \mathbf{s}$ without dementia, $\mathrm{PWD}=$ person/s with dementia, $\mathrm{RN}=$ registered nurse, $\mathrm{VaD}=$ vascular dementia. 


\section{Barriers to Service Accessibility and Use}

\section{Knowledge of Services}

Poor visibility of rural service organizations, and low awareness

of available services, how to use them, and benefits of service use

Practicality and Resources

Geographic remoteness/travel necessity and transportation challenges, costs of services, need for respite, difficulty getting the person with dementia to services, and structure of service provision

\section{Potential Solutions to Barriers}

- Use of a care manager, First Link, or trusted service provider to connect users to other resources

- Use of initial program participation to link users with other resources

- Education on available services and their benefits

- Collaborations and referral between agencies

- Community education to increase public awareness

- Linking former caregivers to new caregivers

- Technological support and education provision (Internet, telehealth/teleconference, phone, video)

- Multiple formats of information dissemination

- Assistance with/provision of transportation

- Assistance with or consideration of CG respite

- Free programming or reduction of costs

- In-home, outreach, or locally accessible service provision

- Fewer program sessions

- Provision of materials that are readily available

- Collaboration between agencies to share accessibility solutions (e.g., collaboration around transportation)

- Recruitment of key local people (e.g., clergy, police, shopkeepers) to provide additional support

\section{Values and Beliefs}

Valuation of independence, reluctance to reach out for help, privacy and confidentiality concerns, belief that caregivers should be family, denial of symptoms

\section{Negative Judgments and Stigma}

Stigma around dementia and use of support services,

fear of abilities or performance being judged negatively

\section{Unacceptability of Services}

Perceptions of services/format as distressing, not suited to current dementia stage, inappropriate for needs, not a "good fit" or incompatible with personal and cultural background, characteristics, and interests, non-person-centred, inflexible, and impermanen
- Use of a care manager, First Link, or trusted service provider to connect users to other resources

- Use of initial program participation to link users with other resources

- Educating users on the benefits of service use in relation to their situation, and addressing misconceptions

- Individual rather than group intervention

- Linking former caregivers to new caregivers

- Educating users on the benefits of service use, and addressing misconceptions

- Individual rather than group support and education

- Support and information via telephone or home visits

- Community education to increase public awareness

- Increased contact between people in the general community and people with dementia

- Person-centred services considering individuals' background, personal characteristics, and interests

- Programmatic activities for people with dementia that are meaningful and enjoyable

- Presentation of information in a way that is appropriate/tailored to the family

- Direct educational approach so users can ask questions

- Culturally safe services, which may include cultural safety training for staff or increased hiring of staff who are familiar with/ members of the culture of users

- Language-matched resources

- Tailoring program to a specific subgroup of participants

- Regular assessment of programming from users' perspectives

- Program flexibility in activities and format

- Appropriate and comfortable setting for programming

- Use of volunteers to maximize sustainability of programs 
therapy (Brotons \& Marti, 2003); horticultural therapy within day programming (Gigliotti, Jarrott, \& Yorgason, 2004); in-hospital support (Bateman, Anderson, Bird, \& Hungerford, 2016; Ervin \& Moore, 2014); cognitivebehavioural and memory training (Jo \& Song, 2016); physical and verbal exercise training (La Rue et al., 2013; La Rue, Felten, \& Turkstra, 2015), and cognitive stimulation therapy (Paddick et al., 2017). Two support groups for caregivers were described (Moore, 2002; O'Connell, Crossley, Cammer, \& Morgan, 2014), and an exercise intervention was aimed at both caregivers and people with dementia (Dal Bello-Haas et al., 2014a). Education-based interventions were primarily targeted towards caregivers and included information on dementia, patient behaviours, formal and informal care, resources and supports, driving, and nutrition (Coogle, 2002; Paul, Johnson, \& Cranston, 2000; Scharf, Bell, \& Smith, 2006; Smith \& Bell, 2005; Taylor, Lindeman, Stothers, Piper, \& Kuipers, 2012; Tomkins \& Bell, 2009).

interventions implemented elements of both support and education, including (a) home visits; (b) case management and referral; (c) group and individual education on dementia and resources; (d) group support and counseling; (e) caregiver skill training on communication, problem solving, and behaviour management; $(\mathrm{f})$ self-care; (g) advocacy; (h) day programming; and (i) respite (Brijoux et al., 2016; Clancy, 2015; Downes, 2013; Glueckauf et al., 2007; Hicken et al., 2017; Nomura et al., 2009).

\section{Education and Support Service Needs, Availability, and Use}

Numerous education and support needs were identified, with a general need for greater information or support for persons with dementia and their caregivers frequently mentioned in qualitative work (see Table 4). The need for education about available resources and services was often highlighted by participants, including service/health providers (Burton, O'Connell, \& Morgan, 2016; Coogle, 2002; Di Gregorio, Ferguson, \& Wiersma, 2015; Edelman et al., 2006; Forbes et al., 2012; Forbes et al., 2006; Gurayah, 2015; Glueckauf et al., 2005; Innes, Szymczynska, \& Stark, 2014; O'Reilly \& Strong, 1997; Smith et al., 2011). When needs were ranked by importance or frequency, the top reported needs included information on dementia in general, treatments, coping with responsive behaviours and challenging symptoms, meaningful activities for the person with dementia, resources/supports, and caregiving and family dynamics (Buettner \& Langrish, 2001; Coogle, 2002; Edelman et al., 2006).

Our review suggests that while many needs were consistent across studies and participants (e.g., information about available resources), needs were also influenced by participants' roles, geographical residence, and dementia stage. Edelman et al. (2006) found that education and support needs often differed between Americans with dementia and their family caregivers, which is an important consideration for interventions. They also reported that while sex of the caregiver did not impact number of information needs, male care recipients reported interest in more topics compared to female care recipients. Sex was examined in another American sample by Li et al. (2012), who found that women were more likely to have unmet service needs compared to men. Two comparative studies suggested that rurality may also influence needs. Rural respondents in the United States rated education regarding understanding and treating dementia as most important while urban respondents most needed information on the emotional and psychological consequences of caregiving (Coogle, 2002); Buettner and Langrish (2001) found in their American sample that rural caregivers were almost twice as likely $(79.3 \%)$ as urban caregivers $(45.2 \%)$ to express the need for formal support with recreation for the person with dementia. Finally, information needs differed depending on the stage of dementia (Forbes et al. 2013; Forbes et al. 2012), and information was required at the time of diagnosis or prospectively in order to understand the progression of dementia, identify "next steps", and plan for the future (Burton et al., 2016; Innes, Blackstock, Mason, Smith, \& Cox 2005; Innes et al., 2014; Sanders \& McFarland, 2002).

Rural participants faced resource challenges, with a majority of non-intervention studies reporting limited and insufficient availability of education and support services. Innes et al. (2005), for example, found that 78 per cent of participants (people with dementia and their caregivers in rural Scotland) reported gaps in available services. Similarly, only 48 per cent of physicians and 19.3 per cent of other health care providers in a rural Canadian sample reported that available support services for people with dementia and their caregivers were adequate (Dal Bello-Haas et al., 2014a). Day programming and respite care (particularly in-home, evening, weekend, and emergency respite) were the specific supports most frequently identified as inadequate or unavailable, in articles from North America, Europe, and Australia (Dal Bello-Haas et al., 2014a; Forbes et al., 2013; Innes et al., 2005; Innes et al., 2014; Mason, Blackstock, Cox, Innes, \& Smith, 2005; McDonnell \& Ryan, 2014; Morgan et al., 2002; Morgan et al., 2015; O'Reilly \& Strong, 1997; Plunkett \& Chen, 2016; Putnam, Pickard, Rodriguez, \& Shear, 2010; Smith et al., 2011; Teel, 2004). Several authors also reported insufficient or unavailable counseling and support services (Dal Bello-Haas et al., 2014a; Morgan et al., 2015; Smith et al., 2011; Teel, 2004). 
Additionally, early stage support was inadequate in some communities (Herron et al., 2016; Herron \& Rosenberg, 2017; Morgan et al., 2002; Innes et al., 2005). Suggesting this is a rurality issue (and not an issue with dementia services in general), only 35 per cent of Bédard, Koivuranta, \& Stuckey's (2004) Canadian rural caregiver sample reported support services were available to them, compared to 88 per cent of their urban sample. Similarly, Alzheimer Society staff reported fewer services provided by other organizations (e.g., day programs) in rural compared to urban locations (Herron et al., 2016). Particular gaps in services were reported for people with young onset dementia and those belonging to an ethnic or sexual minority group (McDonald \& Heath, 2009; Moore, 2002). Finally, limited choices in type, amount, and provider were identified even when services were available (Forbes et al., 2011; Forbes et al., 2013; Innes, Sherlock, \& Cox, 2003; Kelsey \& Laditka, 2006; Mason et al., 2005; O'Reilly \& Strong, 1997). Conversely, Orpin et al. (2014) reported that caregivers in rural Tasmanian communities were generally satisfied with the availability, range, and quality of formal support they received, and Ervin \& Reid (2015) found that only a small minority of caregivers in rural Victoria, Australia, reported support services to be unavailable or did not use offered services.

The use of services among rural caregivers and persons with dementia varied significantly between study populations. Bédard et al. (2004) reported that only 15 per cent of the rural Canadian caregivers in their sample received formal support. Conversely, von Kutzleben et al. (2016) found that only 15.5 per cent of the German caregivers in their study did not use formal services, although it should be noted that the latter study was conducted much more recently. Other proportions of service use in different populations/locations were as follows: All caregivers used at least two of the listed support and education services (Ervin \& Reid, 2015, Australia); 35.8 per cent of caregivers used services (Li et al., 2012, United States); 50 per cent of persons with dementia used services (Nordberg et al., 2005, Sweden); 37 per cent of caregivers used no services (Arai et al., 2000, Japan); over 25 per cent of families used no services (Sun, Kosberg, Kaufman, Leeper, \& Burgin, 2007, United States); and 23 per cent of caregivers used no services (Wenger, Scott, \& Seddon, 2002, United Kingdom). Nordberg et al. (2005) found that men and women had comparable levels of formal care when dementia was "questionable", but that men had more care compared to women with dementia at later stages of impairment.

When examining specific support services, those involving direct assistance to the person with dementia (e.g., help with activities of daily living or home care) and home maintenance were used most frequently (Arai et al., 2000; Burholt, Wenger, \& Scott, 1997; Ervin
\& Reid, 2015; Forbes et al., 2012; Forbes et al., 2006; von Kutzleben et al., 2016; Sun et al., 2007; Wenger et al., 2002). Reported use of support/self-help groups by caregivers and people with dementia was quite low, ranging from 4.8 per cent to 25 per cent (Buettner \& Langrish, 2001; Ervin \& Reid, 2015; Forbes et al., 2006; Innes et al., 2003; Sun et al., 2007). Ervin and Reid found that even among Australian caregivers with selfreported moderate to severe depression, anxiety, and stress, less than half (36-46\%) attended support groups and even fewer utilized counseling or home respite. Consistent with these findings, service providers in Canada reported that existing rural support groups were underutilized (Herron et al., 2016).

Few studies comparing urban and rural samples, however, found differences in use of specific services. Burholt et al. (1997) reported that people with dementia living in rural areas of the United Kingdom were more likely to receive a package of five or more social care services compared to their urban counterparts. Kosloski, Schaefer, Allwardt, Montgomery, \& Karner, (2002) found that American urban caregivers used more average monthly hours of day care and respite (46.2) compared to rural users (35.3); use appeared to be linked to attitudes about caregiving and perceptions of services. Buettner and Langrish (2001) found that over half of the American rural caregivers in their study participated in Alzheimer's education activities, which was significantly higher than the urban caregivers. There were no significant differences in use of support groups, counselling, legal or financial planning, case management, home modification, and homecare and other forms of home support visits (public and private home help, social workers, meals on wheels, voluntary helper, respite night sitters) (Buettner \& Langrish, 2001; Burholt et al., 1997; Forbes et al., 2006).

\section{Barriers to Accessibility and Use}

Our review suggests multiple barriers to accessibility and use of support and education services by people with dementia and their caregivers living in rural areas (Table 4). Barriers reflected five general themes, delineated below: (a) knowledge of services, (b) practicality and resources, (c) values and beliefs, (d) negative judgments and stigma, and (e) unacceptability of services. Since barriers were often reported within qualitative studies that had a broader focus, little information exists about which barriers are most significant from the perspectives of service users.

\section{Knowledge of Services}

Poor awareness of available or eligible services was described within six articles, spanning Canada, the United States, and Scotland (Di Gregorio et al., 2015; 
Forbes et al., 2006; Glueckauf et al., 2005; Herron et al., 2016; Innes et al., 2014; Morgan et al., 2002). Di Gregorio et al. (2015) concluded that a lack of awareness regarding services was common, and that there were limited presence and visibility of organizations providing dementia-related education and support in rural northern communities. Service providers reported higher visibility of their dementia-related support and education services in urban compared to rural areas, with lack of knowledge as a barrier to use (Herron et al. 2016). Moreover, Forbes et al. (2006) found not knowing where to go for services was a unique barrier for their rural sample of people with dementia. In addition to poor awareness of services, families may be unaware of their potential benefits (Morgan et al., 2002).

\section{Practicality and Resources}

Practicality and resource barriers were factors that made it logistically difficult to access or use services. The most frequently reported were geographic distance and transportation, identified in 15 studies across Canada, Scotland, Tanzania, and Australia (Andrews, Morgan, \& Stewart, 2010; Clancy, 2015; Di Gregorio et al., 2015; Forbes et al., 2012; Herron et al., 2016; Innes et al., 2005; Innes et al., 2006; Innes et al., 2003; Innes et al., 2014; Morgan et al., 2002; Morgan et al., 2015; O'Reilly \& Strong, 1997; Paddick et al., 2017; Plunkett \& Chen, 2016; Smith et al., 2011). Services were not always locally available; therefore, distance and long travel times made access difficult (Di Gregorio et al., 2015; Herron et al., 2016; Innes et al., 2005; Innes et al., 2006; Innes et al., 2003; Innes et al., 2014; Morgan et al., 2002; Plunkett \& Chen, 2016; Smith et al., 2011). Transportation was a large part of this challenge, reported by Innes et al. (2005) as the service gap most frequently identified by people with dementia and their caregivers. O'Reilly and Strong (1997) reported that remote caregivers found it challenging to access services in town because the necessary bus was available only twice a day. Similarly, Forbes et al. (2012) noted that because of long distances between respite locations and service users, transportation was generally not offered by organizations. Other challenges with transportation included costs, access to a vehicle, travel time, poor roads, and dependence on others (Innes et al., 2005; Innes et al., 2003; Smith et al., 2011; Paddick et al., 2017).

Financial barriers were identified in eight studies, with costs of services prohibitive for some individuals in Canada, the United Kingdom, Scotland, Australia, and the United States (Andrews et al., 2010; Clarke \& Bailey, 2016; Forbes et al., 2006; Innes et al., 2006; Morgan et al., 2002; O’Reilly \& Strong, 1997; Putnam et al., 2010; Smith et al., 2011; Herron et al., 2016). Morgan et al. (2002) noted that cost was a barrier despite subsidization of services for their Canadian participants, which may be influenced by a reluctance to spend hard-earned money. Socioeconomic status and high costs of (remote) living negatively affected accessibility (Andrews et al., 2010; Herron et al., 2016; \& Smith et al., 2011), and Putnam et al. (2010) noted that "making too much money" could also cause difficulty paying for services (e.g., reduced eligibility for subsidization).

Other practicality and resource barriers included lack of adequate respite so caregivers could access services (Herron et al., 2016; Morgan et al., 2002), and difficulties getting the person with dementia to day care or out-ofhome respite, which could be very disruptive (Innes et al., 2005; Orpin et al., 2014). Additionally, the structure of service provision was noted as a barrier. Insufficient time with health and service providers impacted information dissemination/education and provider awareness of needs (Forbes et al., 2012; Smith et al., 2011), and the process of trying to obtain services (e.g., being on a waiting list) affected accessibility (Forbes et al., 2006; Wenger et al., 2002).

\section{Values and Beliefs}

Independence was the most commonly described value (identified in six articles from Canada, the United Kingdom, and Australia) that hindered service use, as it was coupled with reluctance to ask for or accept help (Clarke \& Bailey, 2016; Forbes et al., 2012; Herron \& Rosenberg, 2017; Morgan et al., 2002; O'Reilly \& Strong, 1997; Wenger et al., 2002). Herron and Rosenberg (2017) described how the salience of independence among their rural Canadian sample of people with dementia and their caregivers contributed to delays accessing support services. Similarly, Forbes (2012) noted caregiver reluctance to impose on others and the desire to conserve resources until services were desperately needed. The emphasis on independence and selfsufficiency was often described as part of the cultural context of rural communities. Some of the qualitative studies from Canada and Japan suggested beliefs around gender and social roles may also deter service use, with men emphasizing independence and fear of emasculation (Herron \& Rosenberg, 2017) and care perceived as women's duty (Arai et al., 2000; Morgan et al., 2002). Participants also valued privacy and had concerns around confidentiality related to service use (Glueckauf et al., 2005; Herron et al., 2016; Innes et al., 2005; Morgan et al., 2002).

Beliefs around caregiving and dementia, particularly the idea that family should be performing the caregiving role, could also be barriers to the use of support services as reported in studies from Canada, Scotland, and Australia (Andrews et al., 2010; Innes et al., 2005; 
Innes et al., 2014; Morgan et al., 2002; Orpin et al., 2014). Andrews et al. (2010) described Canadian northern values around family and respect for older adults as being paramount, and dependence on family members as caregivers. Caregivers were reluctant to entrust responsibility to support providers and reported guilt related to doing so (Morgan et al., 2002; Orpin et al., 2014); guilt was a reason that caregivers refused services (Innes et al., 2005). Denial and lack of awareness of symptoms were also barriers, when people with dementia believed they did not need services or information (Forbes et al., 2013; Forbes et al., 2012; Herron et al., 2016; Morgan et al., 2002).

\section{Negative Judgments and Stigma}

Stigma was reported as a barrier to service use within 10 articles, spanning Canada, Japan, the United States, and Scotland (Arai et al., 2000; Forbes et al., 2013; Forbes et al., 2012; Forbes et al., 2011; Glueckauf et al., 2005; Herron \& Rosenberg, 2017; Herron et al., 2016; Innes et al., 2006; Morgan et al., 2002; Nomura et al., 2009). For example, Forbes et al. (2012) reported caregiver reluctance to disclose a diagnosis and need for help because of stigma around dementia. Fear of stigma was noted as a significant barrier to services where there might be people known to the prospective users (Forbes et al., 2013; Forbes et al., 2011; Morgan et al., 2002). Participants in two studies, from the United States and Canada, described the desire of family caregivers to protect the person with dementia from stigma as being characteristic of small rural communities (Glueckauf et al., 2005; Morgan et al., 2002). People with dementia also described avoidance of social and recreational activities due to fear of negative judgments (Herron \& Rosenberg, 2017). Arai et al. (2000) reported that their sample of Japanese caregivers were concerned about what other people would think or say about service use, perceived stigma around the use of support services (see also Nomura et al., 2009), and feared negative judgments from professionals regarding their house (e.g., cleanliness) or caregiving. Stigma appeared to be of particular concern for daughters and daughters-in-law, who were expected to be dutiful caregivers. The authors' quantitative findings showed that caregiver concern over the judgments of others deterred service use.

\section{Unacceptability of Services}

Perceptions of services as inappropriate or inadequate were identified in 17 studies, from Canada, Japan, Scotland, Ireland, the United States, Japan, and Australia (Clarke \& Bailey, 2016; Forbes et al., 2013; Forbes et al., 2012; Forbes et al., 2006; Herron \& Rosenberg, 2017; Herron et al., 2016; Innes et al., 2005; Innes et al., 2006; Innes et al., 2003; Innes et al., 2014;
McDonnell \& Ryan, 2014; Moore, 2002; Nomura et al., 2009; Orpin et al., 2014; O'Reilly \& Strong, 1997; Putnam et al., 2010; Wenger et al., 2002). Information was not always in an appropriate format for families (for example, the reading level was too difficult or information was presented poorly), and service providers reported that standardized educational material could be intimidating (Forbes et al., 2013; Herron \& Rosenberg, 2017; Innes et al., 2014). Support services were perceived by many participants as unsuitable or inadequate because they were distressing or disruptive to the person with dementia, were not suited to their current stage of dementia, were not in a preferred format (e.g., in-home or individual support), and were inflexible (Clarke \& Bailey, 2016; Forbes et al., 2013; Herron \& Rosenberg, 2017; Innes et al., 2005; Innes et al., 2003; McDonnell \& Ryan, 2014; Nomura et al., 2009; Orpin et al., 2014; O'Reilly \& Strong, 1997). Sons appeared to favour a problem-focused coping style (McDonnell \& Ryan, 2014), and reported available support groups to be unhelpful due to their focus on emotional support rather than caregiver education (Sanders \& McFarland, 2002).

Lack of person-centredness also elicited perceptions of services as unsuitable; many caregivers and people with dementia felt services did not fit their or the person with dementia's personal characteristics, interests, and needs (Clarke \& Bailey, 2016; Forbes et al., 2012; Herron \& Rosenberg, 2017; Innes et al., 2005; Innes et al., 2014; McDonnell \& Ryan, 2014; Moore, 2002). Caregivers and people with dementia in Herron and Rosenberg's (2017) Canadian research delayed accessing support services because they were perceived as inadequate for their needs, assumed lack of abilities (treated users like children), and did not reflect participants' personal and gendered interests. Similarly, Innes et al. (2005) reported that $26 / 45$ caregivers and people with dementia in their study in Scotland rejected services offered to them because they were unsuitable for their needs, inflexible, and not person-centred. Rurality made it more difficult to find services that were acceptable and a good fit, as options were limited (Innes et al., 2006; Mason et al., 2005; Putnam et al., 2010). Moreover, two Canadian studies reported that low continuity of rural support services, volunteers, and staff decreased accessibility and use, and fostered distrust (Forbes et al., 2013; Herron et al., 2016).

\section{Solutions to Accessibility and Use Barriers}

Potential solutions to barriers were suggested within descriptive studies and evident in the design and implementation of interventions and programs. Most of these solutions coalesced around six themes, described below: (a) technological service provision, (b) a "point of entry" to services, (c) accessibility considerations and assistance, 
(d) inter-organization collaboration, (e) education, and (f) tailored or person-centred services. A full list of solutions identified in the literature and the barriers they could mitigate are presented in Table 6.

\section{Technological Service Provision}

Many of the support and education interventions developed for rural populations employed the use of information and communication technologies, including the Internet as a means of information dissemination (Arai, Arai, Mizuno, Kamimura, \& Ikeda, 2017), telehealth/ teleconference (Dal Bello-Haas, O'Connell, Morgan, \& Crossley, 2014b; Hicken et al., 2017; O'Connell et al., 2014; Paul et al., 2000), and telephone (Glueckauf et al., 2007; Moore, 2002; Nomura et al., 2009). Arai et al. (2017), for example, created an online downloadable manual for family caregivers about driving and dementia; Paul et al. (2000) held an interactive teleconference for rural caregivers focused on nutrition for people with dementia; and Glueckauf et al. (2007) developed a telephone-based cognitive behavioural intervention for rural caregivers. Participants in non-intervention studies also reported the usefulness of technologies to deliver information and support to rural populations (Herron et al., 2016; O'Reilly \& Strong, 1997; Smith et al., 2011). Further supporting the use of technologies, Burton et al. (2016) found that 100 per cent of the rural Canadian caregivers and people with dementia who were interested in cognitive rehabilitation would prefer this support via telehealth compared to in-person. Technical difficulties, however, were noted within Canadian and American studies as a potential issue with the use of telehealth/conferencing (Dal Bello-Haas, O'Donnell, Morgan, \& Crossley, 2014b; Paul et al., 2000; O'Connell et al., 2014). Using multiple modalities of support and education provision can mitigate technical difficulties and user discomfort with, or lack of access to, particular technologies (Hicken et al., 2017; Paul et al., 2000).

\section{A "Point of Entry" to Service Use}

Service use may be facilitated by having a "point of entry", such as a case manager, trusted health care or service provider, an Alzheimer Society First Link program, or initial participation in a support or education intervention. An outcome reported in several intervention studies was participants' increased knowledge of, openness to, and use of additional support services (Brijoux et al., 2016; Brotons \& Marti, 2003; Scharf et al., 2006; Taylor et al., 2012; Tomkins \& Bell, 2009). Alzheimer Society service providers described the importance of early connections with families, through First Link, home visits, or telephone consultations (Herron et al., 2016). Orpin et al. (2014) similarly reported that almost all caregivers had developed a strong relationship with one provider, who was a connection point into the system (see also Forbes et al., 2012). As part of their caregiver education and support intervention, Hicken et al. (2017) included a care manager who monitored participants' intervention progress, maintained regular contact with participants and answered their questions, and assisted with referrals. Further demonstrating the utility of such an approach, Sun et al. (2007) found that caregivers with a case manager reported greater use of other services.

\section{Accessibility Assistance}

Participants identified, and some interventions included, non-technological accessibility assistance to facilitate service use. Accessibility considerations for rural populations in Canada, Scotland, Australia, Tanzania, and the United States involved structural decisions around programming such as the provision of in-home and outreach or local services, reduced program sessions, and convenient timing of programming (Clancy, 2015; Innes et al., 2006; La Rue et al., 2013; La Rue et al., 2015; Paddick et al., 2017; Paul et al., 2000; Scharf et al., 2006). For example, La Rue et al. (2013) held intervention sessions (physical exercise and language and memory stimulation) in participants' homes or convenient places in the community. Home visits were noted as an important solution to accessibility issues by Alzheimer Society service providers (Herron et al., 2016). Pragmatic assistance with costs, transportation, and respite were also identified as important to ameliorate accessibility and use barriers, and were reflected in some programs (Coogle, 2002; Innes et al., 2006; Kelsey \& Laditka, 2006; Tomkins \& Bell, 2009). Approximately 75 per cent of the dementia service providers in Innes et al.'s (2006) research provided transportation to users, and more than half of the day program directors surveyed by Kelsey and Laditka (2006) emphasized their efforts to reduce cost barriers. Tomkins and Bell (2009) included a voucher for respite costs as a branch of their intervention, which increased the use of other services.

\section{Inter-organization Collaboration}

Collaboration between organizations and sectors was suggested as a feature of high-quality service provision and a way to enhance service accessibility (Clancy, 2015; Forbes et al., 2012; Innes et al., 2006; Mason et al., 2005; McDonald \& Heath, 2009; O'Reilly \& Strong, 1997). Service providers in Innes et al.'s (2006) research reported that effective partnerships with other agencies allowed them to share knowledge, funding, and transportation schemes, strengthening the accessibility and quality of services (see also Mason et al., 2005). Strong communication and ties between organizations could facilitate referrals to appropriate services and increase 
caregiver support at an early stage (Forbes et al., 2012; O'Reilly and Strong, 1997). Recruitment of volunteer assistance in service provision was also perceived to increase the quality and quantity of services (McDonald \& Heath), and as a potential strategy to increase their sustainability (La Rue et al., 2013; La Rue et al., 2015).

\section{Education}

Public and caregiver education on dementia and available resources was identified as important to ameliorate knowledge, beliefs and values, and stigma barriers to service use (Herron et al., 2016; Morgan et al., 2002). Participants in Morgan et al.'s (2002) work suggested caregivers need education on available resources in a way that helps them make connections to their own life and illustrates potential benefits. The need for better community education (including increased visibility of people with dementia) was also noted as a way to reduce stigma. Such public and community education was provided, along with a variety of other services, by the Hawthorn House in Australia (Downes, 2013). An educational DVD developed by Taylor et al. (2012) for Aboriginal Australians was also a resource for the public in addition to caregivers. Education on available resources for people with dementia and their caregivers was a major component of some interventions (Brijoux et al., 2016; Coogle, 2002; Nomura et al., 2009). For example, the educational intervention developed by Coogle (2002) included directories of local resources in the target communities, and workshops included information on resources and services. Nomura et al. (2009) used a case study example as part of caregiver education to illustrate the potential benefits of support service use and reduce misperceptions; this strategy reduced caregiver reluctance to use services.

\section{Tailored and Person-Centred Services}

Tailoring services to a specific population, and providing person-centred services, were important aspects of many interventions (Bateman et al., 2016; Downes, 2013; Ervin \& Moore, 2014; Gigliotti et al., 2004; Moore, 2002; Nomura et al., 2009; O'Connell et al., 2014; Paddick et al., 2017; Paul et al., 2000; Taylor et al., 2012). Moore (2002) developed a support group tailored to the needs of rural gay and lesbian caregivers in the United States, who had previously struggled to access suitable supports. Similarly, sharing support with people who have similar circumstances, ages, and life situations was of immense benefit to spousal caregivers to people with atypical young-onset dementias (O'Connell et al., 2014).

Consideration of cultural factors in service provision, including language-appropriate resources, was also important (Nomura et al., 2009; Paddick et al., 2017; Smith et al., 2011; Taylor et al., 2012). In the development of their cognitive stimulation therapy in rural Tanzania, Paddick et al. (2017) considered the cultural context and educational backgrounds of participants by finding appropriate buildings for sessions, timing them to fit around household work, farming, and village ceremonies, and considering participants' knowledge and experiences when designing tasks. Taylor et al. (2012) emphasized the importance of culturally safe services, and concluded that incorporating Aboriginal languages and localizing content enhanced participant engagement with their educational intervention. Paul et al. (2000) ensured that the language and level of information in their nutrition education was tailored to their target audience. A direct educational approach may also be advantageous, so that caregivers and people with dementia can ask questions and information can be tailored to families (Forbes et al., 2013; Innes et al., 2014; Paul et al., 2000).

Person-centred interventions which took into account users' personal backgrounds, characteristics, interests, and desires were also described (Bateman et al., 2016; Downes, 2013; Ervin \& Moore, 2014; Gigliotti et al., 2004; Nomura et al., 2009; Paddick et al., 2017). Gigliotti et al (2004) included horticultural activities in day programming to provide a broader range of activities that participants perceived as meaningful. In the hospital support programs, volunteers learned the personal characteristics and interests of patients so they could engage them in meaningful and enjoyable conversation and activities (Bateman et al., 2016; Ervin \& Moore, 2014). A key element of the Hawthorn House was that services were individualized and supported users' needs, interests, and desires; evaluation of these services was very positive (Downes, 2013). Flexibility was identified as necessary to adapt services to rural contexts and individual needs (Clancy, 2015; Innes et al., 2005; Nomura et al., 2009; Smith et al., 2011). For example, after realizing the importance of spirituality to their elderly Japanese service users, Nomura et al. (2009) adapted their cognitive rehabilitation intervention to include temples and shrines as settings for the recall of autobiographical memories. Person-centred services were identified as a priority by participants in McDonald and Heath's (2009) research, and a personcentred perspective was implemented in day programs by learning the past hobbies, interests, and current preferences of users, changing programming to match interests and desires, providing meaningful activities, creating comfortable settings, and regularly evaluating activities from users' perspectives (Kelsey \& Laditka, 2006).

\section{Discussion}

The current review investigated the education and support needs of people with dementia and their caregivers 
living in rural areas, the availability and use of education and support services, barriers to these services, and solutions to identified barriers. Findings suggested that in the majority of rural populations studied, there were limited and insufficient services available to people with dementia and their caregivers. Specific gaps included day programming and respite care, counseling and support services, early stage support, and services for minority groups. Moreover, low density of services meant that participants had little choice in services regardless of fit. This limited service availability is in contrast to studies not focused on rural populations, wherein the presence of available services is often not perceived as an issue (e.g., Brodaty, Thomson, Thompson, \& Fine, 2005; Macleod, Tatangelo, McCabe, \& You, 2017; Robinson et al., 2009). Organizational "rationing" of services, insular rural culture, transportation costs, and difficulty accessing communities were identified as barriers to service development in rural communities (McDonald and Health, 2009).

Use of education and support services varied widely between studies, from 15 per cent of rural participants (Bédard et al., 2004) to 100 per cent of rural caregivers surveyed (Ervin \& Reid, 2015). Home maintenance and services providing direct assistance to the person with dementia, generally in-home, were used the most frequently, while minimal use of support groups was reported. Although studies comparing service use among urban and rural samples found few significant differences, it should be noted that studies reporting no differences (Buettner \& Langrish, 2001; Burholt et al., 1997; Forbes et al., 2006) did not compare the services identified most frequently as unavailable in rural communities: day programs and different types of respite. Kosloski et al. (2002) did find urban participants used more monthly hours of day care and in-home respite compared to rural participants, although they did not assess population differences in use/non-use. Use findings are therefore relatively consistent with reported availability of services. The large amount of informal support reported by participants in several studies (Bédard et al., 2004; Innes et al., 2003; Li et al., 2012; Nordberg et al., 2005; Wenger, Burholt, \& Scott, 1998; Wenger et al., 2002) may also contribute to minimal levels of formal service use. For example, 85 per cent of the rural caregivers in Bédard et al.'s (2004) research received only informal support (compared to 33\% of urban caregivers), but reported more total weekly hours of support than their urban counterparts. Wenger et al. (1998) reported that approximately three quarters of the assistance received by people with dementia was informal, generally from a relative living in the same residence. Strong informal community support networks were also described in several studies, where family, neighbours, and other community members looked out for the person with dementia and provided needed assistance (Di Gregorio et al., 2015; Herron \& Rosenberg, 2017; Innes et al., 2003).

It is important to note that in terms of service use and availability, most of the focus in the reviewed articles was on instrumental support, such as meal preparation and respite, psychological support in the form of counseling or support groups (mainly for caregivers), and education about dementia and treatment. There are other forms of support for persons with dementia and their caregivers (e.g., support with sleep, communication, exercise, driving cessation, legal decision-making) that were not examined in articles assessing accessibility and use of rural support services. Additionally, less research focus was devoted to the availability or use of supports for understanding and responding to care recipient distress and behaviours, despite this being identified as a need and addressed in some intervention studies (e.g., Hicken et al., 2017; Glueckauf et al., 2007). When available, such supports may also be underutilized, as suggested by Ervin and Reid's (2015) finding that few $(10 \%)$ of their rural Australian caregivers surveyed had used a Dementia Behaviour Management Advisory Service offering phone support, and 15 per cent did not know this service was available. Such support is beneficial, with reviews illustrating an association between what are often called "responsive behaviours" and caregiver burden and mental health issues (Ornstein \& Gaugler, 2012; Van der Lee, Bakker, Duivenvoorden, \& Dröes, 2014). It is important, therefore, to understand the extent to which such supports are available and utilized by rural caregivers.

As our understanding of how to best support persons with dementia and their caregivers grows, there is also increasing recognition of the importance of social inclusion. Although the need for social inclusion was identified in some of the qualitative work reviewed (e.g., Forbes et al., 2011), it was unclear to what extent formal supports to address social isolation were available and used by rural populations. Empirical attention to other types of formal support would contribute to a more holistic understanding of what rural caregivers and persons with dementia need, have access to, and use.

Many barriers to accessibility and use of services by people with dementia and their caregivers were evident, including (a) poor knowledge of services, (b) practicality and resource barriers, (c) values and beliefs, (d) negative judgments and stigma related to both dementia and use of services, and (e) service inadequacy or inappropriateness. Findings illustrate the importance of making services and pathways to access known to families, which was a need we frequently identified in the current review. Sun et al. (2007) 
concluded that rural families use formal services primarily as a result of outreach efforts by professionals, highlighting the need for proactive education strategies and connections to service providers. Lack of knowledge of services is not unique to rural areas, and in fact has been identified in the broader literature as a significant barrier to dementia service provision (Macleod et al., 2017; Phillipson, Jones, \& Magee, 2014; Robinson et al., 2009; Sutcliffe, Roe, Jasper, Jolley, \& Challis, 2013). Similarly, perceptions of services as inflexible, inappropriate for needs, and not tailored or person-centred are barriers regardless of rurality, as are some of the values and beliefs around caregiving (guilt, reluctance to ask for assistance) and care recipient resistance (Bieber, Nguyen, Meyer, \& Stephan, 2019; Boots, Wolfs, Verhey, Kempen, \& de Vugt, 2015; Brodaty et al., 2005; Greenwood \& Smith, 2015; Macleod et al., 2017; Phillipson \& Jones, 2012).

Despite stigma's having been reported as a barrier among urban residents in some studies (e.g., Boots et al., 2015; Mukadam, Cooper, \& Livingston, 2013), Macleod et al. (2017) did not find this in their urban sample and suggested an increased awareness and normalization of dementia and service use. Although stigma may be decreasing rurally as well, it may also be that diminished privacy and confidentiality makes stigma a bigger problem in rural communities as suggested within the articles we reviewed. Lack of choice among services in rural areas may similarly exacerbate issues with inadequacy or inappropriateness of services. Unsurprisingly, geographical and transportation barriers were salient and appear relatively unique to rural populations.

\section{Recommendations}

Strategies to mitigate accessibility and use barriers should be considered in the development and implementation of rural dementia services. In our review, we have identified a number of solutions to barriers, including (a) the use of information and communication technologies, (b) having a point of entry to service use, (c) accessibility assistance, (d) inter-organization collaboration, (e) education, and (f) the development of tailored and person-centred services.

We would like to specifically highlight several of these solutions. First, the use of technology in dementia care is rapidly increasing, and reviews suggest positive effects of technology-based support and education interventions (e.g., Boots, de Vugt, van Knippenberg, Kempen, \& Verhey, 2014; Lee, 2015). Information and communication technologies can ameliorate geographical and transportation barriers, and facilitate tailored education and interventions. Although inconsistent access to broadband Internet in rural and remote Canada (an issue in many rural areas globally) has been identified as a barrier to information and communication technologies (Ogilvie \& Eggleton, 2016), they remain a promising avenue of dementia-related education and support service development where feasible.

Second, supporting a point of entry to service use may increase knowledge about services, how to access them, and their potential benefits. Having a central point of contact to facilitate service access is desired by caregivers (Macleod et al., 2017; Robinson et al., 2009). A point of entry could take many forms; Dementia Service Centres in Austria offer initial referral and screening for dementia, so that patients are brought into a hub of linked services even before a diagnosis is obtained (Auer, Span, \& Reisberg, 2015). A recent Canadian Senate report (Ogilvie \& Eggleton, 2016) encouraged the implementation of the Alzheimer Society of Canada's First Link program across Canada. Such point-of-entry initiatives should be supported so that persons with dementia and their caregivers are aware of available services and their benefits and access is facilitated.

Third, working to develop dementia education and support that is tailored and person-centred is important to meeting the needs of families. Understanding both population or community-based needs and the specific needs of individual people with dementia and their caregivers is important for service provision (Morrisby, Joosten, \& Ciccarelli, 2018). Person-centred services can be achieved by comprehensively assessing the needs, preferences, and abilities of service users, and providing culturally sensitive programs that can be adapted to sub-populations (Whitlatch \& Orsulic-Jeras, 2018). Our review suggests that flexibility and one-onone contact are also ways to enhance the personcentredness of services. A non-person-centred approach is more than a barrier to service use; relationship-centred care is important to the experience of service use, individual well-being, and social inclusion (Ryan, Nolan, Reid, \& Enderby, 2008). As the best outcomes for people with dementia occur when services are "timely, responsive, flexible, and tailored to individual need" (Dawson et al., 2015, p. 25), these characteristics should be reflected in education and support services. A person or relationship-centred approach has been highlighted as a priority for dementia care in Canada (Canadian Academy of Health Sciences, 2019) and globally (Prince et al., 2016), and should be emphasized in service development, provision, and the training of health and support care providers.

Evaluation of education and support services is also recommended. This may include ongoing informal evaluation by rural service users to ensure that their needs and interests are being met (see, e.g., Kelsey \& 
Laditka, 2006), process evaluation to determine whether services are functioning as intended, or outcome evaluation to illustrate program impact and efficacy. Although multiple (including qualitative) methodologies offer important information about the effectiveness of services, few intervention studies used the randomized control designs that would be considered strong evidence of program efficacy. Another important direction for evaluation efforts is the increased inclusion of persons with dementia in research, as participants and even co-researchers (e.g., Mann \& Hung, 2018). The authors of a recent, non-rural-focused review of factors influencing access and use of formal community dementia services concluded that more attention to the perspectives of persons with dementia was required in research and service development (Bieber et al., 2019). Greater inclusion of persons with dementia and their caregivers as co-researchers may increase the person-centred focus of support services research, and reveal previously understudied aspects of support required by families. The importance of engaging persons living with dementia and their caregivers in meaningful ways, including as part of research efforts, was highlighted as a priority by the Canadian Academy of Health Sciences' recent assessment of evidence and best practices to inform development of a Canadian Dementia Strategy (2019).

Additionally, efforts must be made towards the sustainability of high-quality services. Many empirically validated interventions are not established as part of ongoing service delivery despite their efficacy (Gitlin, Marx, Stanley, \& Hodgson, 2015), which does not address the needs of people with dementia and their families and may lead to community distrust (Forbes et al., 2013; Herron \& Rosenberg, 2016). Effective and person-centred services should be developed in partnership with existing community organizations and infrastructure to ensure that supports are sustainable.

Finally, better incorporation of sex and gender is required to understand their intersection with rurality and service needs, use, and barriers. The reviewed research suggests being a female person with dementia is related to unmet service needs while males receive more formal care, and that gendered norms around caregiving, independence, and coping strategies may affect rural individuals' use of services. The broader (non-rural) literature also suggests potential influences of sex and gender on how people with dementia and their caregivers engage with services, such as the presence of higher unmet care needs for women with dementia and a greater propensity for women to have confidence in and use formal services, although female caregivers report lower use of in-home respite services compared to men (e.g., Baker \& Robertson, 2008; Bartlett, Gjernes, Lotherington, \& Obstefelder, 2018;
Forbes et al., 2008; Greenwood \& Smith, 2015; Phillipson et al., 2014; Zodikoff, 2007). There is limited research examining sex and gender in the context of dementia care, to the point where Bartlett et al. (2018) have characterized this literature as "gender blind"; this must be redressed (Tierney et al., 2017). It is also important to assess potential sex differences in the acceptability and effectiveness of support and education services for people with dementia and their caregivers, in order to better meet the needs of these populations.

\section{Limitations}

Limitations include the non-inclusion of grey literature, which would help to build a comprehensive description of available rural services and gaps. The current review could be a good complement to environmental scans in specific geographical areas. Another limitation was the broad focus of the review, which meant relevant information was sometimes described in articles with little depth (e.g., stigma would be mentioned but not elaborated upon). Finally, we did not limit inclusion to any specific definition of rural; varying definitions meant that population density and distance from urban centres differed greatly between studies and was often not clarified. It should also be noted that although this review synthesized information across rural populations, rural communities are heterogeneous and have unique characteristics, strengths, and challenges. This is a particularly important caveat given the international nature of this review, although efforts have been made to identify the geographic context of reviewed studies, and study locations can be viewed in Tables 4 and 5 .

\section{Conclusions}

This review illustrates the needs of rural people with dementia and their caregivers, and suggests limited availability of dementia-related support and education services in many communities. A number of barriers to the accessibility and use of existing services persist, some of which are unique or characteristic of rural settings and others which must also be addressed in urban communities. Although our review illustrates challenges with rural dementia support and education, promising solutions and innovations within rural service provision were also evident. These findings can help inform the development of dementia-related support and education services that are accessible to, and used by, rural populations. As dementia care continues to evolve in Canada and globally, opportunities should be pursued to improve rural dementia-related services through the use of information and communication technologies, accessibility assistance, inter-organization collaboration, supporting point of entry service models, and a person or relationship-centred approach to both research and care. 


\section{References}

Alzheimer's Disease International. (2009). World Alzheimer Report 2009: The Global Prevalence of Dementia. Retrieved from https://www.alz.co.uk/research/files/World AlzheimerReport.pdf

Andrews, M. E., Morgan, D. G., \& Stewart, N. J. (2010). Dementia awareness in northern nursing practice. Canadian Journal of Nursing Research, 42(1), 56-73. Retrieved from http://journals.sagepub.com/home/cjn

Arai, Y., Arai, A., Mizuno, Y., Kamimura, N., \& Ikeda, M. (2017). The creation and dissemination of downloadable information on dementia and driving from a social health perspective. Psychogeriatrics, 17(4), 262-266. doi:10.1111/ psyg.12229

Arai, Y., Sugiura, M., Miura, H., Washio, M., \& Kudo, K. (2000). Undue concern for others' opinions deters caregivers of impaired elderly from using public services in rural Japan. International Journal of Geriatric Psychiatry, 15(10), 961-968. doi:10.1002/1099-1166 (200010)15:10<961::AID-GPS225>3.0.CO;2-T

Arksey, H., \& O’Malley, L. (2005). Scoping studies: Towards a methodological framework. International Journal of Social Research Methodology, 8(1), 19-32. doi:10. 1080/1364557032000119616

Auer, S. R., Span, E., \& Reisberg, B. (2015). Dementia service centres in Austria: A comprehensive support and early detection model for persons with dementia and their caregivers-Theoretical foundations and model description. Dementia, 14(4), 513-527. doi:10 $1177 / 1471301213502214$

Baker, K. L., \& Robertson, N. (2008). Coping with caring for someone with dementia: Reviewing the literature about men. Aging \& Mental Health, 12(4), 413-422. doi:10. $1080 / 13607860802224250$

Bateman, C., Anderson, K., Bird, M., \& Hungerford, C. (2016). Volunteers improving person-centered dementia and delirium care in a rural Australian hospital. Rural and Remote Health, 16(2), 3667. Retrieved from http:// www.rrh.org.au

Bartlett, R., Gjernes, T., Lotherington, A.-T., \& Obstefelder, A. (2018). Gender, citizenship and dementia care: A scoping review of studies to inform policy and future research. Health and Social Care in the Community, 26(1), 14-26. doi: $10.1111 /$ hsc. 12340

Bieber, A., Nguyen, N., Meyer, G., \& Stephan, A. (2019). Influences on the access to and use of formal community care by people with dementia and their informal caregivers: A scoping review. BMC Health Services Research, 19(1), 88. doi:10.1186/s12913-018-3825-z

Bédard, M., Koivuranta, A., \& Stuckey, A. (2004). Health impact on caregivers of providing informal care to a cognitively impaired older adult: Rural versus urban settings. Canadian Journal of Rural Medicine, 9(1), 15-23.
Retrieved from http://www.ovid.com/site/catalog/ journals /1146.jsp

Boots, L. M. M., de Vugt, M. E., van Knippenberg, R. J. M., Kempen, G. I. J. M., \& Verhey, F. R. J. (2014). A systematic review of Internet-based supportive interventions for caregivers of patients with dementia. International Journal of Geriatric Psychiatry, 29(4), 331-344. doi:10. 1002/gps.4016

Boots, L. M. M., Wolfs, C. A. G., Verhey, F. R. J., Kempen, G. I. J., \& de Vugt, M. E. (2015). Qualitative study on needs and wishes of early-stage dementia caregivers: The paradox between needing and accepting help. International Psychogeriatrics, 27(6), 927-936. doi:10.1017/ S1041610214002804

Bourke, L., Humphreys, J., Wakerman, J., \& Taylor, J. (2012). Understanding rural and remote health: A framework for analysis in Australia. Health \& Place, 18(3), 496-503. doi: 10.1016/j.healthplace.2012.02.009

Brijoux, T., Kricheldorff, C., Hüll, M., \& Bonfico, S. (2016). Supporting families living with dementia in rural areas. Deutsches Ärzteblatt International, 113(41), 681-687. doi:10. 3238/arztebl.2016.0681

Brodaty, H., Thomson, C., Thompson, C., \& Fine, F. (2005). Why caregivers of people with dementia and memory loss don't use services. International Journal of Geriatric Psychiatry, 20(6), 537-546. doi:10.1002/gps.1322

Brotons, M., \& Marti, P. (2003). Music therapy with Alzheimer's patients and their family caregivers: A pilot project. Journal of Music Therapy, 40(2), 138-150. doi:10.1093/jmt/40.2.138

Buettner, L. L., \& Langrish, S. (2001). Rural vs. urban caregivers of older adults with probable Alzheimer's disease. Activities, Adaptation \& Aging, 24(2), 51-65. doi: 10.1300/J016v24n02_04

Burholt, V., Wenger, G. C., \& Scott, A. (1997). Dementia disability and contact with formal services: A comparison of dementia sufferers and non-sufferers in rural and urban settings. Health and Social Care in the Community, 5(6), 384-397. doi:10.1111/j.1365-2524.1997. tb00136.x

Burton, R., O'Connell, M. E., \& Morgan, D. G. (2016). Exploring interest and goals for videoconferencing delivered cognitive rehabilitation with rural individuals with mild cognitive impairment or dementia. NeuroRehabilitation, 39(2), 329-342. doi:10.3233/NRE161364

Canadian Academy of Health Sciences. (2019). Improving the quality of life and care of persons living with dementia and their caregivers: Canadian Academy of Health Sciences' assessment of dementia care in Canada. Retrieved from https: / / www.cahsacss.ca/wp-content/uploads/2019/01/Report.pdf

Canadian Home Care Association. (2006). The delivery of home care services in rural and remote communities in 
Canada. Retrieved from http:/ / www.cdnhomecare.ca/ content.php? doc $=220$

Canadian Institute for Health Information. (2018). Dementia in Canada. Retrieved from https://www.cihi.ca/en/ dementia-in-canada

Clancy, A. (2015). Practice model of a dementia outreach service in rural Australia. Australian Journal of Rural Health, 23(2), 87-94. doi:10.1111/ajr.12147

Clarke, C. L., \& Bailey, C. (2016). Narrative citizenship, resilience and inclusion with dementia: On the inside or on the outside of physical and social places. Dementia, 15 (3), 434-452. doi:10.1177/1471301216639736

Coogle, C. L. (2002). The Families Who Care Project: Meeting the educational needs of African American and rural family caregivers dealing with dementia. Educational Gerontology, 28(1), 59-71. doi:10. $1080 / 036012702753304494$

Dal Bello-Haas, V., Cammer, A., Morgan, D., Stewart, N., \& Kosteniuk, J. (2014a). Rural and remote dementia care challenges and needs: Perspectives of formal and informal care providers residing in Saskatchewan, Canada. Rural and Remote Health, 14(3), 2747. Retrieved from http://www.rrh.org.au/journal/article/2747

Dal Bello-Haas, V. P. M., O'Connell, M. E., Morgan, D. G., \& Crossley, M. (2014b). Lessons learned: Feasibility and acceptability of a telehealth-delivered exercise intervention for rural-dwelling individuals with dementia and their caregivers. Rural and Remote Health, 14(3), 2715. Retrieved from http://www.rrh.org.au/ journal/article/2715

Dam, A. E., de Vugt, M. E., Klinkenberg, I. P., Verhey, F. R., \& van Boxtel, M. P. (2016). A systematic review of social support interventions for caregivers of people with dementia: Are they doing what they promise? Maturitas, 85, 117-130. doi:10.1016/j.maturitas.2015.12.008

Dawson, A., Bowes, A., Kelly, F., Velzke, K., \& Ward, R. (2015). Evidence of what works to support and sustain care at home for people with dementia: A literature review with a systematic approach. BMC Geriatrics, 15 (1), 59. doi:10.1186/s12877-015-0053-9

Dickinson, C., Dow, J., Gibson, G., Hayes, L., Robalino, S., \& Robinson, L. (2017). Psychosocial intervention for carers of people with dementia: What components are most effective and when? A systematic review of systematic reviews. International Psychogeriatrics, 19(1), 31-43. doi: $10.1017 /$ S1041610216001447

Di Gregorio, D., Ferguson, S., \& Wiersma, E. (2015). From beginning to end: Perspectives of the dementia journal in northern Ontario. Canadian Journal on Aging, 34(1), 100-112. doi:10.1017/S0714980814000531

Downes, S. (2013). The Eden Principles in dementia respite care: Carers' experiences. Quality in Ageing and Older Adults, 14(2), 105-115. doi:10.1108/14717791311327051
Edelman, P., Kuhn, D., Fulton, B. R., \& Kyrouac, G. A. (2006). Information and service needs of persons with Alzheimer's disease and their family caregivers living in rural communities. American Journal of Alzheimer's Disease $\mathcal{E}$ Other Dementias, 21(4), 226-233. doi:10. $1177 / 1533317506290664$

Ervin, K., \& Moore, S. (2014). Rural nurses' perceptions of a volunteer program in an acute setting: Volunteers delivering person-centred care for patients with dementia and delirium. Open Journal of Nursing, 4, 27-33. doi:10.4236/ojn.2014.41005 P

Ervin, K., \& Reid, C. (2015). Service utilization by carers of people with dementia in rural Victoria. Australasian Journal on Ageing, 34(4), E1-E6. doi:10.1111/ajag.12162

Forbes, D., Blake, C., Thiessen, E., Finkelstein, S., Gibson, M., Morgan, D. G., ... Culum, I. (2013). Dementia care knowledge sharing within a First Nations community. Canadian Journal on Aging, 32(4), 360-374. doi:10.1017/ S0714980813000457

Forbes, D., Finkelstein, S., Blake, C. M., Gibson, M., Morgan, D. G., Markle-Reid, M., ... Thiessen, E. (2012). Knowledge exchange throughout the dementia care journey by Canadian rural community-based health care practitioners, persons with dementia, and their care partners: An interpretive descriptive study. Rural and Remote Health, 12, 2201. doi:10.7939/R3K93161Z

Forbes, D., Jansen, S. L., Markle-Reid, M., Hawranik, P., Morgan, D., Henderson, S., ... Kingston, D. (2008). Gender differences in use and availability of home and community-based services for people with dementia. Canadian Journal of Nursing Research, 40(1), 38-59. Retrieved from http://cjnr.archive.mcgill.ca/article/ view / 2107

Forbes, D. A., Morgan, D., \& Janzen, B. L. (2006). Rural and urban Canadians with dementia: Use of health care services. Canadian Journal on Aging, 25(3), 321-330. doi: $10.1353 /$ cja. 2007.0003

Forbes, D., Ward-Griffin, C., Kloseck, M., Mendelsohn, M., StAmant, O., DeForge, R., \& Clark, K. (2011). "Her world gets smaller and smaller with nothing to look forward to": Dimensions of social inclusion and exclusion among rural dementia care networks. Rural Nursing and Health Care, 11(2), 27-42. Retrieved from http://rnojournal. binghamton.edu//index.php/RNO/issue/view/4

Gitlin, L. N., Marx, K., Stanley, I. H., \& Hodgson, N. (2015). Translating evidence-based dementia caregiving interventions into practice: State-of-the-science and next steps. Gerontologist, 55(2), 210-226. doi:10.1093/geront/ gnu123

Gould, E., \& Basta, P. (2013). Home is where the heart is-For people in all stages of dementia. Generations: Journal of the American Society on Aging, 37(3), 74-78. Retrieved from http://www.asaging.org/generations-journal-americansociety-aging 
Glueckauf, R. L., Stine, C., Bourgeois, M., Pomidor, A., Rom, P., Young, M. E., ... Ashley, P. (2005). Alzheimer's Rural Care Healthline: Linking rural caregivers to cognitivebehavioral intervention for depression. Rehabilitation Psychology, 50(4), 346-354. doi:10.1037/0090-5550.50.4.346

Glueckauf, R. L., Jeffers, S. B., Sharma, D., Massey, A. J., Shuford Davis, W., Wesley, L. M., ... Martin, C. (2007). Telephone-based cognitive-behavioral intervention for distressed rural dementia caregivers. Clinical Gerontologist, 31(1), 21-41. doi:10.1300/J018v31n01_03

Gigliotti, C. M., Jarrott, S. E., \& Yorgason, J. (2004). Harvesting health: Effects of three types of horticultural therapy activities for persons with dementia. Dementia, 3(2), 161-180. doi:10.1177/1471301204042335

Greenwood, N., \& Smith, R. (2015). Barriers and facilitators for male carers in accessing formal and informal support: A systematic review. Maturitas, 82(2), 162-169. doi:10. 1016/j.maturitas.2015.07.013

Gurayah, T. (2015). Caregiving for people with dementia in a rural context in South Africa. South African Family Practice, 57(3), 194-197. doi:10.1080/20786190.2014.976946

Health Quality Ontario. (2018). Quality Standards. Dementia: Care for people living in the community. Retrieved from https:// www.hqontario.ca/portals/0/documents/evidence/ quality-standards / qs-dementia-clinician-guide-en.pdf

Herron, R. V., \& Rosenberg, M. W. (2017). "Not there yet": Examining community support from the perspective of people with dementia and their partners in care. Social Science E Medicine, 173, 81-87. doi:10.1016/j.socscimed. 2016.11.041

Herron, R. V., Rosenberg, M. W., \& Skinner, M. W. (2016). The dynamics of voluntarism in rural dementia care. Health $\mathcal{E}$ Place, 41, 34-41. doi:10.1016/j.healthplace.2016.06.008

Hicken, B. L., Daniel, C., Luptak, M., Grant, M., Kilian, S., \& Rupper, R. W. (2017). Supporting caregivers of rural veterans electronically (SCORE). The Journal of Rural Health, 33(3), 305-313. doi:10.1111/jrh.12195

Huis in het Veld, J. G., Verkaik, R., Mistiaen, P., van Meijel, B., \& Francke, A. (2015). The effectiveness of interventions in supporting self-management of informal caregivers of people with dementia; a systematic meta review. BMC Geriatrics, 15(1), 147. doi:10.1186/s12877-015-0145-6

Innes, A., Blackstock, K., Mason, A., Smith, A., \& Cox, S. (2005). Dementia care provision in rural Scotland: Service users' and carers' experiences. Health and Social Care in the Community, 13(4), 354-365. doi:10.1111/j.13652524.2005.00569.x

Innes, A., Cox, S., Smith, A., \& Mason, A. (2006). Service provision for people with dementia in rural Scotland: Difficulties and innovations. Dementia, 5(2), 249-270. doi:10.1177/1471301206062253

Innes, A., Sherlock, K., \& Cox, S. (2003). Seeking the views of people with dementia on services in rural areas. Journal of Dementia Care, 11, 37-39.
Innes, A., Szymczynska, P., \& Stark, C. (2014). Dementia diagnosis and post-diagnostic support in Scottish rural communities: Experiences of people with dementia and their families. Dementia, 13(2), 233-247. doi:10. $1177 / 1471301212460608$

Jensen, M., Agbata, I. N., Canavan, M., \& McCarthy, G. (2015). Effectiveness of educational interventions for informal caregivers of individuals with dementia residing in the community: Systematic review and meta-analysis of randomized controlled trials. International Journal of Geriatric Psychiatry, 30(2), 130-143. doi:10.1002/gps.4208

Jo, H. K., \& Song, M. R. (2016). Effects of the "Happy Together" integrated cognitive behavior program on elderly people with dementia being cared for at home in rural areas. Asia-Pacific Psychiatry, 8(2), 172-174. doi:10. 1111 /appy. 12235

Kasper, J. D., Freedman, V. A., Spillman, B. C., \& Wolff, J. L. (2015). The disproportionate impact of dementia on family and unpaid caregiving to older adults. Health Affairs, 34(10), 1642-1649. doi:10.1377/hlthaff.2015.0536

Kelsey, S. G., \& Laditka, S. B. (2006). Evaluating best practices for social model programs for adults with Alzheimer's disease in South Carolina. Home Health Care Services Quarterly, 24(4), 21-46. doi:10.1300/J027v24n04_02

Kosloski, K., Schaefer, J. P., Allwardt, D., Montgomery, R. J. V., \& Karner, T. X. (2002). The role of cultural factors on clients' attitudes toward caregiving, perceptions of service delivery, and service utilization. Home Health Care Services Quarterly, 21(3-4), 65-88. doi:10.1300/ J027v21n03_04

La Rue, A., Felten, K., Duschene, K., MacFarlane, D., Price, S., Zimmerman, S., \& Hafez, S. (2013). Language-enriched exercise plus socialization for older adults with dementia: Translation to rural communities. Seminars in Speech and Language, 34(3), 170-184. doi:10.1055/s-0033-1358370

La Rue, A., Felten, K., \& Turkstra, L. (2015). Intervention of multi-modal activities for older adults with dementia translation to rural communities. American Journal of Alzheimer's Disease and Other Dementias, 30(5), 468-477. doi:10.1177/1533317514568888

Lee, E. (2015). Do technology-based support groups reduce care burden among dementia caregivers? A review. Journal of Evidence-Informed Social Work, 12(5), 474-487. doi:10.1080/15433714.2014.930362

Lepore, M., Ferrell, A., \& Wiener, J. M. (2017). Living arrangements of people with Alzheimer's disease and related dementias: Implications for services and supports. Washington, DC: US Department of Health \& Human Services. Retrieved from https:/ / aspe.hhs.gov/ pdf-report/living-arrangements-people-alzheimersdisease-and-related-dementias-implications-servicesand-supports

Levac, D., Colquhoun, H., \& O'Brien, K. K. (2010). Scoping studies: Advancing the methodology. Implementation Science, 5(1), 69. doi:10.1186/1748-5908-5-69 
Li, H., Kyrouac, G. A., McManus, D. Q., Cranston, R. E., \& Hughes, S. (2012). Unmet home care service needs of rural older adults with Alzheimer's disease: A perspective of informal caregivers. Journal of Gerontological Social Work, 55(5), 409-425. doi:10. 1080/01634372.2011.650318

Macleod, A., Tatangelo, G., McCabe, M., \& You, E. (2017). "There isn't an easy way of finding the help that's available." Barriers and facilitators of service use among dementia family caregivers: A qualitative study. International Psychogeriatrics, 29(5), 765-776. doi:10.1017/ S1041610216002532

Mann, J., \& Hung, L. (2018). Co-research with people living with dementia for change. Action Research, 1-18. doi:10. $1177 / 1476750318787005$

Mason, A., Blackstock, K., Cox, S., Innes, A., \& Smith, A. (2005). Dementia services in rural areas: Nursing implications. Nursing Older People, 17(9), 20-23. Retrieved from https: / /journals.rcni.com/doi/abs/10.7748/nop2005. 12.17.9.20.c2398

McDonald, A., \& Heath, B. (2009). Developing services for people with dementia. Working with Older People, 13(3), 18-21. Retrieved from https://journals.rcni.com/doi/ abs/10.7748/nop2005.12.17.9.20.c2398

McDonnell, E., \& Ryan, A. A. (2014). The experience of sons caring for a parent with dementia. Dementia, 13(6), 788-802. doi:10.1177/1471301213485374

Moore, W. R. (2002). Lesbian and gay elders: Connecting care providers through a telephone support group. Journal of Gay and Lesbian Social Services, 14(3), 23-41. doi:10.1300/ J041v14n03_02

Morgan, D., Innes, A., \& Kosteniuk, J. (2011). Dementia care in rural and remote settings: A systematic review of formal or paid care. Maturitas, 68, 17-33. doi:10.1016/j. maturitas.2010.09.008

Morgan, D. G., Kosteniuk, J. G., Stewart, N. J., O'Connell, M. E., Kirk, A., \& Crossley, M. (2015). Availability and primary health care orientation of dementia-related services in rural Saskatchewan, Canada. Home Health Care Services Quarterly, 34(3-4), 137-158. doi:10. 1080/01621424.2015.1092907

Morgan, D. G., Kosteniuk, J. G., O'Connell, M. E., Dal BelloHaas, V., Stewart, N. J., \& Karunanayake, C. (2016). Dementia-related work activities of home care nurses and aides: Frequency, perceived competence, and continuing education priorities. Educational Gerontology, 42(2), 120-135. doi:10.1080/03601277.2015.1083390

Morgan, D. G., Semchuk, K. M., Stewart, N. J., \& D'Arcy, C. (2002). Rural families caring for a relative with dementia: Barriers to use of formal services. Social Science \& Medicine, 55(7), 1129-1142. doi:10.1016/S0277-9536(01)00255-6

Morrisby, C., Joosten, A., \& Ciccarelli, M. (2018). Do services meet the needs of people with dementia and carers living in the community? A scoping review of the international literature. International Psychogeriatrics, 30(1), 5-14. doi: $10.1017 /$ S1041610217001491

Mukadam, N., Cooper, C., \& Livingston, G. (2013). Improving access to dementia services for people from minority ethnic groups. Current Opinion in Psychiatry, 26, 409-414. doi:10.1097/YCO.0b013e32835ee668

National Institute for Health and Care Excellence. (2010). Dementia: Support in health and social care. Quality Standard. Retrieved from https://www.nice.org.uk/ guidance/qs1

National Institute for Health and Care Excellence. (2013). Dementia: Independence and wellbeing. Quality standard. Retrieved from https:/ / www.nice.org.uk/guidance/qs30

Nomura, M., Makimoto, K., Kato, M., Shiba, T., Matsuura, C., Shigenobu, K., ... Ikeda, M. (2009). Empowering older people with early dementia and family caregivers: A participatory action research study. International Journal of Nursing Studies, 46(4), 431-441. doi:10.1016/j.ijnurstu. 2007.09.009

Nordberg, G., von Strauss, E., Kåreholt, I., Johansson, L., \& Wimo, A. (2005). The amount of informal and formal care among non-demented and demented elderly personsResults from a Swedish population-based study. International Journal of Geriatric Psychiatry, 20(9), 862-871. doi:10.1002/gps.1371

O'Connell, M., Crossley, M., Cammer, A., \& Morgan, D. (2014). Development and evaluation of a telehealth videoconferenced support group for rural spouses of individuals diagnosed with atypical early-onset dementias. Dementia, 13(3), 382-395. doi:10.1177/1471301212474143

Ogilvie, K. K., \& Eggleton, A. (2016). Dementia in Canada: A national strategy for dementia-friendly communities. Standing Senate Committee on Social Affairs, Science and Technology. Retrieved from https://sencanada.ca/ content/sen/committee/421/SOCI/Reports/SOCI_ 6thReport_DementiaInCanada-WEB_e.pdf

O'Reilly, M. T., \& Strong, J. (1997). Caring for someone with dementia in a rural town part 2: Services. Australian Journal on Ageing, 16(4), 194-197. Retrieved from https: / / onlinelibrary.wiley.com/doi/abs/10.1111/j.17416612.1997.tb01051.x

Ornstein, K., \& Gaugler, J. (2012). The problem with "problem behaviors": A systematic review of the association between individual patient behavioral and psychological symptoms and caregiver depression and burden within the dementia patient-caregiver dyad. International Psychogeriatrics, 24(10), 1536-1552. doi:10. $1017 /$ S1041610212000737

Orpin, P., Stirling, C., Hetherington, S., \& Robinson, A. (2014). Rural dementia carers: Formal and informal sources of support. Ageing \& Society, 34(2), 185-208. doi:10.1017/ S0144686x12000827

Paddick, S.-M., Mkenda, S., Mbowe, G., Kisoli, A., Gray, W. K., Dotchin, C. L. ... Walker, R. W. (2017). Cognitive 
stimulation therapy as a sustainable intervention for dementia in sub-Saharan Africa: Feasibility and clinical efficacy using a stepped-wedge design. International Psychogeriatrics, 29(6), 979-989. doi:10.1017/S104161 0217000163

Paul, L., Johnson, A. O., \& Cranston, G. M. (2000). A successful videoconference satellite program: Providing nutritional information on dementia to rural caregivers. Educational Gerontology, 26(5), 415-425. doi:10.1080/036012700 50111841

Phillipson, L., \& Jones, S. C. (2012). Use of day centers for respite by help-seeking caregivers of individuals with dementia. Journal of Gerontological Nursing, 38(4), 24-37. doi:10.3928/00989134-20120307-05

Phillipson, L., Jones, S. C., \& Magee, C. (2014). A review of the factors associated with the non-use of respite services by carers of people with dementia: Implications for policy and practice. Health and Social Care in the Community, 22 (1), 1-12. doi:10.1111/hsc.12036

Plunkett, R., \& Chen, P. (2016). Supporting healthy dementia culture: An exploratory study of the church. Journal of Religion and Health, 55(6), 1917-1928. doi:10.1007/s10943015-0165-8

Prince, M., Wimo, A., Guerchat, M., Ali, G.-C., Wu, T.-T., \& Prina, M. (2015). World Alzheimer Report 2015: The global impact of dementia. London, UK: Alzheimer's Disease International. Retrieved from https://www.alz.co.uk/ research/WorldAlzheimerReport2015.pdf

Prince, M., Comas-Herrera, A., Knapp, M., Guerchet, M., \& Karaglannidou, M. (2016). World Alzheimer Report 2016: Improving healthcare for people living with dementia. London, UK: Alzheimer's Disease International. Retrieved from https://www.alz.co.uk/research/ WorldAlzheimerReport2016.pdf

Putnam, M., Pickard, J. G., Rodriguez, C., \& Shear, E. (2010). Stakeholder perspectives on policies to support family caregivers of older adults with dementia. Journal of Family Social Work, 13(2), 173-190. doi:10.1080/10522150903487479

Robinson, A., Elder, J., Emden, C., Lea, E., Turner, P., \& Vickers, J. (2009). Information pathways into dementia care services. Dementia, 8(1), 17-37. doi:10. $1177 / 1471301208099051$

Ryan, T., Nolan, M., Reid, D., \& Enderby, P. (2008). Using the Senses Framework to achieve relationship-centered dementia care services. Dementia, 7(1), 71-93. doi:10. $1177 / 1471301207085368$

Sanders, S., \& McFarland, P. (2002). Perceptions of caregiving role by sons caring for a parent with Alzheimer's disease. Journal of Gerontological Social Work, 37(2), 61-76. doi:10. 1300/J083v37n02_06

Scharf, L., Bell, P. A., \& Smith, S. A. (2006). Number of training sessions does not change program effectiveness. Dementia, 5(4), 559-569. doi:10.1177/1471301206069937
Smith, S., \& Bell, P. A. (2005). Examining the effectiveness of the Savvy Caregiver Program among rural Colorado residents. Rural and Remote Health, 5(3), 466. Retrieved from https: / / www.rrh.org.au/journal/article/466

Smith, K., Flicker, L., Shadforth, G., Carroll, E., Ralph, N., Atkinson, D., ... LoGuidice, D. (2011). 'Gotta be sit down and worked out together': Views of Aboriginal caregivers and service providers on ways to improve dementia care for Aboriginal Australians. Rural and Remote Health, 11(2), 1650. Retrieved from http://www.rrh.org.au/journal/ article/1650

Sun, F., Kosberg, J. I., Kaufman, A. V., Leeper, J. D., \& Burgin, L. D. (2007). Formal services utilization by family caregivers of persons with dementia living in rural southeastern USA. Rural Social Work and Community Practice, 12(2), 22-30.

Sutcliffe, C. L., Roe, B., Jasper, R., Jolley, D., \& Challis, D. J. (2013). People with dementia and carers' experiences of dementia care and services: Outcomes of a focus group study. Dementia, 14(6), 769-787. doi:10. $1177 / 1471301213511957$

Szymczynska, P., Innes, A., Mason, A., \& Stark, C. (2011). A review of diagnostic process and postdiagnostic support for people with dementia in rural areas. Journal of Primary Care \& Community Health, 2(4), 262-276.

Taylor, K. A., Lindeman, M. A., Stothers, K., Piper, K., \& Kuipers, P. (2012). Intercultural communications in remote Aboriginal Australian communities: What works in dementia education and management. Health Sociology Review, 21(2), 208-219. doi:10.5172/hesr.2012. 21.2.208

Teel, C. S. (2004). Rural practitioners' experiences in dementia diagnosis and treatment. Aging \& Mental Health, 8(5), 422-429. doi:10.1080/13607860410001725018

Tierney, M. C., Curtis, A. F., Chertkow, H., \& Rylett, R. J. (2017). Integrating sex and gender into neurodegeneration research: A six-component strategy. Alzheimer's E Dementia: Translational Research $\mathcal{E}$ Clinical Interventions, 3(4), 660-667. doi:10.1016/j.trci.2017.10.006

Tomkins, S. A., \& Bell, P. A. (2009). Examination of a psychoeducational intervention and a respite grant in relieving psychosocial stressors associated with being an Alzheimer's caregiver. Journal of Gerontological Social Work, 52(2), 89-104. doi:10.1080/01634370802561877

Toseland, R. W., McCallion, P., Gerber, T., Dawson, C., Gieryic, S., \& Guilamo-Ramos, V. (1999). Use of health and human services by community-residing people with dementia. Social Work, 44(6), 535-548. doi:10.1093/ sw / 44.6.535

Tricco, A. C., Lillie, E., Zarin, W., O’Brien, K. K., Colquhoun, H., Levac, D., ... Straus, S.E. (2018). PRISMA extension for scoping reviews (PRISMA-ScR): Checklist and explanation. Annals of Internal Medicine, 169(7), 467-473. doi:10.7326/M18-0850 
van der Lee, J., Bakker, T. J. E. M., Duivenvoorden, H. J., \& Dröes, R.-M. (2014). Multivariate models of subjective caregiver burden in dementia: A systematic review. Ageing Research Reviews, 15, 76-93. doi:10.1016/j.arr.2014.03.003

von Kutzleben, M., Reuther, S., Dortmann, O., \& Holle, B. (2016). Care arrangements for community-dwelling people with dementia as perceived by informal carersA cross-sectional pilot survey in a provincial-rural setting. Health and Social Care in the Community, 24(3), 283-296. doi:10.1111/hsc.12202

Wenger, G. C., Burholt, V., \& Scott, A. (1998). Dementia and help with household tasks: A comparison of cases and non-cases. Health E Place, 4(1), 33-44. doi:10.1016/S13538292(97)00024-5

Wenger, G. C., Scott, A., \& Seddon, D. (2002). The experience of caring for older people with dementia in a rural area: Using services. Aging $\mathcal{E}$ Mental Health, 6(1), 30-38. doi:10. $1080 / 13607860120101040$

Whitlatch, C. J., \& Orsulic-Jeras, S. (2018). Meeting the informational, educational, and psychosocial support needs of persons living with dementia and their family caregivers. The Gerontologist, 58(1), S58-S73. doi:10.1093/ geront/gnx162

Wimo, A., Jönsson, L., Bond, J., Prince, M., \& Winblad, B. (2013). The worldwide economic impact of dementia 2010. Alzheimer's E Dementia, 9, 1-11. doi:10.1016/j.jalz. 2012.11.006
World Health Organization. (2012). Dementia: A public health priority. Geneva, CHE: Author. Retrieved from http:// www.who.int/mental_health/publications/dementia_ report_2012/en/

World Health Organization. (2015). Supporting informal caregivers of people living with dementia. Geneva, CHE: Author. Retrieved from http://www.who.int/mental_ health/neurology/dementia/dementia_thematicbrief_ informal_care.pdf

United Kingdom Department of Health. (2013). Dementia: A state of the nation report on dementia care and support in England. Retrieved from https://assets.publishing. service.gov.uk/government/uploads/system/uploads/ attachment_data/file/262139/Dementia.pdf

Vandepitte, S., Van Den Noortgate, N., Putman, K., Verhaeghe, S., Verdonck, C., \& Annemans, L. (2016). Effectiveness of respite care in supporting informal caregivers of persons with dementia: A systematic review. International Journal of Geriatric Psychiatry, 31 (12), 1277-1288. doi:10.1002/gps.4504

Zodikoff, B. D. (2007). Gender differences in the community service use attitudes of older spousal caregiver-care recipient couples. Home Health Care Services Quarterly, 26(2), 1-20. https://www.ncbi.nlm.nih.gov/ pubmed/17537708 